\title{
14. TEMPERATURE AND SALINITY OF FLUID INCLUSIONS IN ANHYDRITE AS INDICATORS OF SEAWATER ENTRAINMENT AND HEATING IN THE TAG ACTIVE MOUND ${ }^{1}$
}

\author{
Margaret Kingston Tivey, ${ }^{2}$ Rachel A. Mills, ${ }^{3}$ and Damon A.H. Teagle ${ }^{4}$
}

\begin{abstract}
Microthermometric analyses of fluid inclusions, carried out on individual anhydrite crystals from samples recovered at depths from 0 to $>120 \mathrm{mbsf}$ within the Trans-Atlantic Geotraverse (TAG) active hydrothermal mound, indicate high temperatures $\left(>337^{\circ} \mathrm{C}\right)$ throughout the TAG- 1 and TAG-2 areas and suggest that temperatures at depths greater than 100 mbsf are in excess of $380^{\circ}$ to $390^{\circ} \mathrm{C}$. Samples from the TAG-5 area indicate a wider and lower range of temperatures $\left(187^{\circ}-337^{\circ} \mathrm{C}\right)$. Salinities of fluids in all inclusions analyzed fall well within the range of measured salinities in mid-ocean ridge vent fluids. Coupling data from fluid inclusion analyses with Sr-isotopic analyses of anhydrite crystals from the same locations allows determination of both the proportions of hydrothermal fluid and seawater comprising the fluids that formed the anhydrite crystals and the temperature of the fluid mixtures. These data provide evidence for seawater entrainment and significant conductive heating of seawater/hydrothermal fluid mixtures within the mound. Conductive heat gain can occur as fluids are transported through veins bounded by conductive sulfide-rich breccias. Estimated flow rates to allow for conductive heating are on the order of 0.02 to $0.08 \mathrm{~kg} / \mathrm{s}$, and geochemical calculations indicate that on the order of $10^{-2} \mathrm{~mol}$ of anhydrite should precipitate per kg of fluid. By assuming that between $1 \%$ and $10 \%$ of the $225 \mathrm{MW}$ convective heat flux from the Black Smoker Complex is used to heat seawater, it is estimated that the existing $\sim 2 \times 10^{4} \mathrm{~m}^{3}$ of anhydrite present within the TAG active mound could have been deposited in 80 to $800 \mathrm{yr}$. The convective process of entraining and heating seawater may be responsible for cooling black smoker fluids from $>380^{\circ} \mathrm{C}$ to the temperature of $366^{\circ} \mathrm{C}$ currently measured in orifices of chimneys that compose the Black Smoker Complex.
\end{abstract}

\section{INTRODUCTION}

The Trans-Atlantic Geotraverse (TAG) active hydrothermal mound is located $2.5 \mathrm{~km}$ east of the neovolcanic zone at $26^{\circ} 08 \mathrm{~N}$ in the middle of a 40-km-long ridge segment on the Mid-Atlantic Ridge. The mound measures 150 to $200 \mathrm{~m}$ in diameter, exhibits $50 \mathrm{~m}$ of relief, and is covered entirely by hydrothermal precipitates. Geochemical studies of solids and fluids recovered from the surface of the mound have provided crucial evidence for entrainment of seawater into the mound and for ongoing zone refinement within the deposit (Tivey et al., 1995; Edmond et al., 1995). In the fall of 1994, 17 holes were drilled in the TAG active hydrothermal mound during Leg 158 of the Ocean Drilling Program in an effort to investigate subsurface portions of the mound. Recovered material, including substantial amounts of anhydrite, provide further evidence for significant entrainment of seawater into the mound.

In order to better understand this entrainment process, detailed studies of anhydrite within the mound have been carried out. These include fluid inclusion analyses to determine the temperature and salinity of the fluids responsible for formation of anhydrite, Sr-isotopic analyses to deduce relative proportions of seawater and hydrothermal fluid involved in the formation of anhydrite, and examination of rareearth element (REE) concentrations of anhydrite to investigate the evolution of fluids within the mound. Here we report on the fluid inclusion analyses. Sr-isotope and REE analyses from a similar sample suite are discussed in detail by Mills et al. (Chap. 10, this volume) and Humphris (Chap. 12, this volume). Sulfur and O-isotope, O- and Srisotope, and fluid inclusion analyses of alternative suites of anhydrite

'Herzig, P.M., Humphris, S.E., Miller, D.J., and Zierenberg, R.A. (Eds.), 1998. Proc. ODP, Sci. Results, 158: College Station, TX (Ocean Drilling Program).

${ }^{2}$ Department of Marine Chemistry and Geochemistry, Woods Hole Oceanographic Institution, Woods Hole, MA 02543, U.S.A. mktivey@whoi.edu

${ }^{3}$ Southampton Oceanography Centre, University of Southampton, Southampton SO14 3ZH, United Kingdom.

${ }^{4}$ Department of Geological Sciences, University of Michigan, Ann Arbor, MI 48109-1063, U.S.A. samples from within the mound are reported by Chiba et al. (Chap. 6, this volume), Teagle et al. (Chap. 22, this volume), and Petersen et al. (Chap. 13, this volume).

\section{THE TAG ACTIVE HYDROTHERMAL MOUND}

The TAG active hydrothermal mound is located at a depth of 3670 meters below sea level (mbsl) within the larger TAG hydrothermal field on $100 \mathrm{ka}$ crust, based on spreading rates (Rona et al., 1993). The distribution of high- and low-temperature venting on the surface of the mound, and of sample types, is asymmetrical (Tivey et al., $1995)$. High-temperature $\left(363^{\circ} \mathrm{C}\right)$ black smoker activity is strongly focused and localized northwest of the center of the mound (at the Black Smoker Complex). Fluids exhibiting lower temperatures $\left(260^{\circ}-300^{\circ} \mathrm{C}\right)$ and less vigorous flow rates emanate from many small (1-2 m) chimneys concentrated in the southeastern quadrant of the mound: the "Kremlin" area (Thompson et al., 1988). Low-temperature fluids percolate through the hydrothermal precipitates over patchy areas of the top and sides of the mound and through areas on the apron surrounding the mound. Results of heat-flow studies include that conductive heat-flow values are extremely variable; there is very high heat flow on the south and southeast sides of the mound, and also high heat flow in sediments on the seafloor surrounding the mound to the northeast, northwest, and southwest, and there is a band of very low heat flow 20 to $50 \mathrm{~m}$ west of the Black Smoker Complex, suggesting an area of shallow recharge (Becker and Von Herzen, 1996).

Considerable work has been done on samples collected from the surface of the mound. The preliminary description of the geologic setting and geochemistry of solids, reported by Thompson et al. (1988), is based on dredged samples and samples recovered during three Alvin dives in 1986. Geochronological studies of samples from the TAG active mound suggest that hydrothermal activity has been intermittent over the past $20,000 \mathrm{yr}$, with a periodicity of 5000-6000 $\mathrm{yr}$, and that the current activity commenced about $50 \mathrm{yr}$ ago (Lalou et al., 1990, 1993). Edmond et al. (1995) carried out time-series studies 
of vent fluids from the TAG active mound that indicate that there are currently two distinct, but related, fluid compositions exiting the mound, and that the compositions of fluids have remained relatively stable over a period of $5 \mathrm{yr}$. White smoker fluids exiting the Kremlin area are approximately $60^{\circ}$ to $90^{\circ} \mathrm{C}$ cooler than black smoker fluids, and are considerably more acidic, and less $\mathrm{Fe}$ - and $\mathrm{H}_{2} \mathrm{~S}$ - rich; these differences are attributed to the white smoker fluid being a mix of roughly five parts black smoker fluid and one part seawater, with precipitation of $\mathrm{Fe}$-sulfide within the mound accounting for the low $\mathrm{Fe}$, $\mathrm{H}_{2} \mathrm{~S}$, and $\mathrm{pH}$ (Edmond et al., 1995). Analyses of the REE compositions of vent fluids suggest that, except for Eu, white smoker fluids exhibit lower REE concentrations than black smoker fluids; however, white smoker fluids show a significantly larger Eu anomaly (Mitra et al., 1994). Investigations of REEs in solids from the mound surface led to the conclusion that precipitation of anhydrite within the mound is responsible for removal of REEs (Mills and Elderfield, 1995). Detailed mineralogical and geochemical studies indicate that sample types associated with focused flow from the Black Smoker Complex on the upper terrace are all enriched in Co and Se. In contrast, samples from the white smoker chimneys, and blocks of sulfide exposed on the lower terrace of the mound, are enriched in $\mathrm{Zn}, \mathrm{Au}, \mathrm{Ag}, \mathrm{Sb}$, $\mathrm{Cd}$, and $\mathrm{Pb}$ (Tivey et al., 1995). The range of sample types, their chemistry, and the relationship between black and white smoker fluid have been explained by a model that involves entrainment of seawater at two levels in the mound (Tivey et al., 1995). At the Black Smoker Complex, focused fluid flow leads to entrainment of seawater into the sides of the complex on the upper terrace at depths less than $3650 \mathrm{mbsl}$, resulting in formation of massive anhydrite. Seawater is also entrained into the main portion of the mound below 3650 mbsl depth, resulting in precipitation of anhydrite and sulfide within the mound as seawater mixes with black smoker fluid. Mineral deposition modifies the $\mathrm{pH}$, concentrations of metals, and $\mathrm{H}_{2} \mathrm{~S}$ in the fluid mixture, forming white smoker fluid from black smoker fluid. Preliminary geochemical modeling of this process successfully reproduced the chemistry of white smoker fluid by considering mixing, conductive cooling, and precipitation within the mound; calculations predict that the proportions of precipitates being deposited within the mound from the mixing process are $\sim 19$ parts anhydrite to 8 parts pyrite and 1 part chalcopyrite (Tivey et al., 1995).

Not surprisingly, one of the significant findings of Leg 158 is that there is abundant anhydrite present within the TAG mound. The deepest penetration into the active mound, to 125 meters below seafloor (mbsf), was in the TAG-1 area, located $~ 20$ m southeast of the black smoker complex. Recovered core reveals a sequence of sulfidesulfate-silicate breccias underlain by silicified wallrock and chloritized basalt breccias (Fig. 1; Humphris et al., 1995; Humphris, Herzig, Miller, et al., 1996). In the TAG-2 area, located on the southeast edge of the mound near the Kremlin area, penetration was to 54.3 mbsf and pyrite and pyrite-silica breccias with anhydrite in veins and vugs were recovered. Anhydrite was not recovered in core from either the TAG-3 area, located on the lower terrace about $55 \mathrm{~m}$ south of the Black Smoker Complex, or the TAG-4 area, located on the upper terrace about 5 to $25 \mathrm{~m}$ west of the Black Smoker Complex. At the TAG-5 area, located near the northern margin of the upper terrace, about 20 to $30 \mathrm{~m}$ north-northeast of the Black Smoker Complex, the deepest penetration was to $59.4 \mathrm{mbsf}$, and pyrite, pyrite-anhydrite, and pyrite-silica breccias were recovered. In the TAG-1, TAG2, and TAG-5 areas, anhydrite occurs in vugs, in veins (up to $45 \mathrm{~cm}$ thick in the TAG-1 area), as matrix in sulfide-silicate-sulfate breccias, and on broken surfaces of pyrite-silica, siliceous wallrock, and chloritized basalt breccias. A combination of studies was made to provide information on the temperature and salinity of fluids that formed the anhydrite and on the relative proportions of seawater and hydrothermal fluid involved. These data allow examination of the processes and consequences of seawater entrainment and mixing within the mound.

\section{METHODS}

Microthermometric analyses of fluid inclusions were carried out on individual anhydrite crystals using a Fluid Inc. adapted U.S. Geological Survey gas-flow heating and freezing stage, following the procedures of Roedder (1984). Standardization of the stage was accomplished by measuring phase transitions within synthetic fluid inclusion samples at $-56.6^{\circ}, 0.0^{\circ}$, and $+374.1^{\circ} \mathrm{C}$. Replicate measurements of homogenization and freezing point depression temperatures were done on individual inclusions; progressive heating and cycling were used to avoid and test for leaking of inclusions (e.g., Kelley et al., 1993). Temperature measurements were reproducible to $\pm 0.1^{\circ} \mathrm{C}$ during freezing and $\pm 0.5^{\circ} \mathrm{C}$ during heating. Recognizing concerns related to inclusions in anhydrite, all measurements were made on either clusters of primary inclusions, or along single arrays, in which all inclusions displayed similar phase ratios, and homogenization temperatures were within $5^{\circ}-10^{\circ} \mathrm{C}$ of adjacent inclusions. Salinities were calculated from freezing-point depression temperatures using data and equations from Bodnar (1993), and are expressed as wt\% $\mathrm{NaCl}$ equivalent. Homogenization temperatures were corrected for pressure effects using the equation of Zhang and Frantz (1987).

Geochemical calculations of fluid mixing and heating were carried out using the computer code MINEQL (Westall et al., 1976), modified for use at high temperature (Tivey and McDuff, 1990). The thermodynamic database used was SUPCRT92 (Johnson et al., 1992), with the addition of data for $\mathrm{HCl}^{\circ}$ and $\mathrm{CuCl}^{\circ}$ from Sverjensky et al. (1991) and Ding and Seyfried (1992a), respectively, and with substitution of data for $\mathrm{FeCl}_{2}{ }^{\circ}$ from Ding and Seyfried (1992b).

\section{RESULTS}

\section{Description of Inclusions}

Fluid inclusion analyses were performed on individual anhydrite crystals picked from broken surfaces, matrix, vugs, and veins from depths between 20.76 and $120.89 \mathrm{mbsf}$ (from cores from Holes 957C, 957E, and 957F) at the TAG-1 area, between 9.08 and 44.85 mbsf (from cores from Holes 957A and $957 \mathrm{H}$ ) at the TAG-2 area, and between 15.92 and $57.99 \mathrm{mbsf}$ (from cores from Holes $957 \mathrm{O}$ and 957P) at the TAG-5 area (see Fig. 1). In addition, measurements were made on anhydrite crystals picked from a massive anhydrite sample recovered from the surface of the mound in the TAG-1 area using the submersible Alvin (Sample ALV1677-2). Similar sample suites were used for complementary studies of REEs (Humphris, Chap. 12, this volume), and Sr-isotopes (Mills et al., Chap. 10, this volume).

Individual anhydrite crystals are tabular, ranging in size from 0.5 to $3 \mathrm{~mm}$. Information on whether crystals were from vugs, veins, matrix, or broken surfaces, and on host sample types, is given in Table 1. Inclusions were classified as primary and secondary following the criteria of Roedder (1984). The majority of inclusions are primary two-phase fluid inclusions, occurring in abundance parallel to crystal faces (Fig. 2A). Inclusion size varies from 3 to $30 \mu \mathrm{m}$, and most inclusions are rectangular or rectilinear; a small subset is round, appearing circular in cross section. Thin, tubular inclusions are present, but were avoided owing to concerns about leaking. Secondary twophase fluid inclusions present along healed microfractures are less common. They range in size from 4 to $25 \mu \mathrm{m}$, and are either rectangular or circular in shape (Fig. 2B). These inclusions may be pseudosecondary inclusions, (i.e., they may have formed during the fractur- 


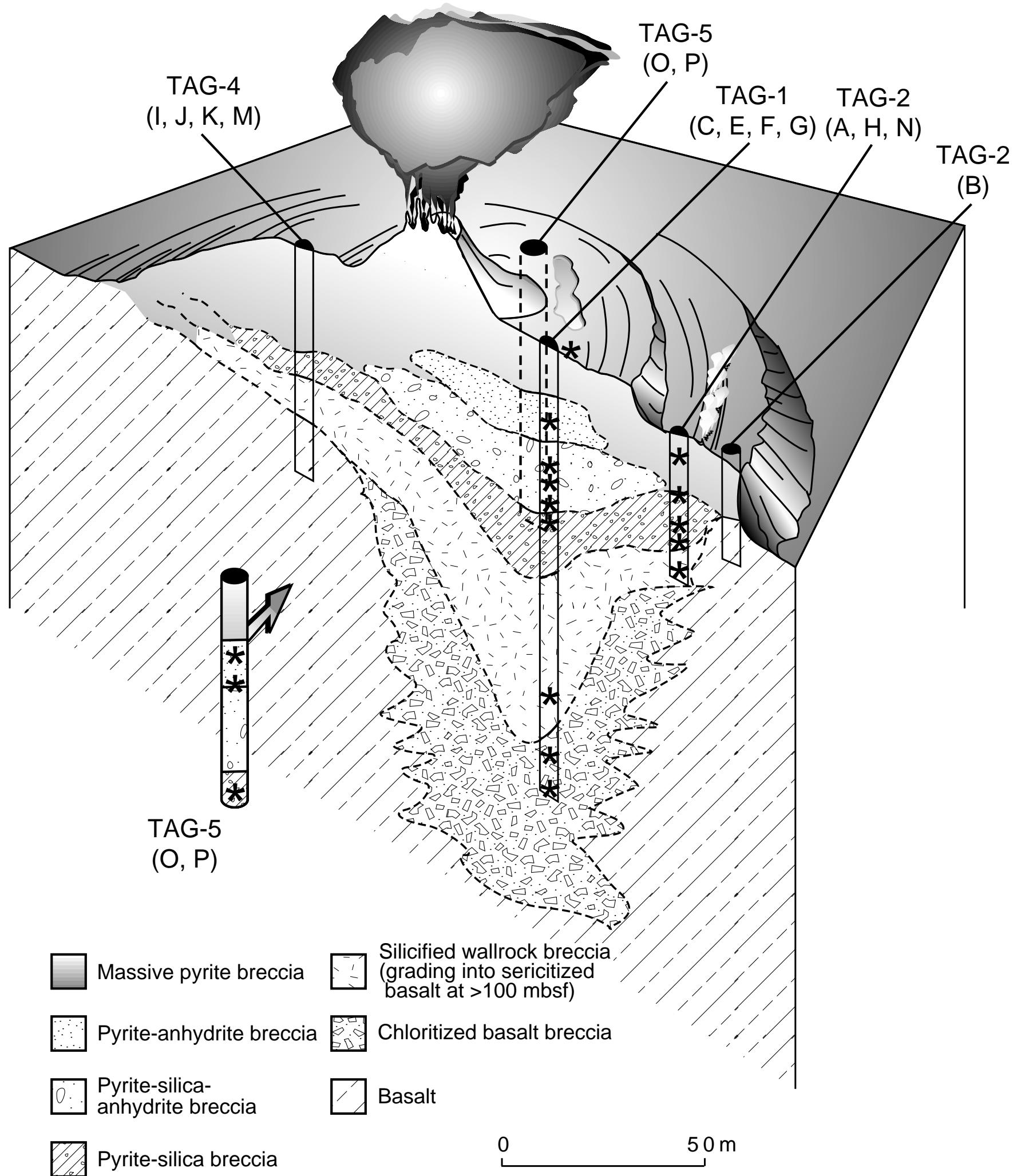

Figure 1. Diagram of the TAG active hydrothermal mound showing the distribution of venting at the surface, the surface morphology, the location of drilling areas TAG-1 through TAG-5, and a schematic view of the internal structure of the mound based on drilling results (from Humphris et al., 1995). Locations of samples used in the fluid inclusion study are indicated by the asterisks. 
Table 1. Origin of anhydrite crystals used in fluid inclusion study.

\begin{tabular}{|c|c|c|}
\hline $\begin{array}{l}\text { Core, section, interval } \\
(\mathrm{cm})\end{array}$ & $\begin{array}{l}\text { Depth } \\
\text { (mbsf) }\end{array}$ & Sample description \\
\hline \multicolumn{3}{|l|}{ TAG-1 } \\
\hline ALV1677-2 & 0 & Massive anhydrite \\
\hline \multicolumn{3}{|l|}{$158-957 \mathrm{C}-$} \\
\hline $7 \mathrm{~N}-01,126-128$ & 20.76 & Vein in nodular siliceous pyrite-anhydrite breccia, with py \\
\hline $11 \mathrm{~N}-01,131-134$ & 32.01 & B anded vein with some $\mathrm{hm}$ \\
\hline $11 \mathrm{~N}-03,121-123 \mathrm{~V}$ & 34.82 & Vein in pyrite-silica breccia, with cp \\
\hline $11 \mathrm{~N}-03,121-123 \mathrm{I}$ & 34.82 & Interstitial in pyrite-silica breccia, with py \\
\hline $15 \mathrm{~N}-02,43-45$ & 43.83 & Vein in silicified wallrock breccia \\
\hline $15 \mathrm{~N}-04,26-34$ & 46.66 & Thin vein against surface of nodular pyrite-silica breccia, with py \\
\hline \multicolumn{3}{|l|}{ 158-957E- } \\
\hline $12 \mathrm{R}-1,0-3$ & 91.80 & Broken surface of silicified wallrock breccia \\
\hline $17 \mathrm{R}-1,8-15$ & 116.18 & Broken surface of chloritized basalt breccia \\
\hline $18 \mathrm{R}-1,19-25$ & 120.89 & Vein in chloritized basalt breccia, with py \\
\hline \multicolumn{3}{|l|}{ TAG-2 } \\
\hline \multicolumn{3}{|l|}{$158-957 \mathrm{H}-$} \\
\hline $1 \mathrm{~N}-1,38-46$ & 9.08 & Vein and matrix of cp-rich porous massive pyrite \\
\hline $3 \mathrm{~N}-1,53-63$ & 18.23 & Matrix of porous nodular pyrite breccia \\
\hline $5 \mathrm{~N}-2,48-58$ & 28.08 & $0.5-\mathrm{cm}$-wide vein on side of py clast from silicified wallrock breccia \\
\hline $5 \mathrm{~N}-2,79-84 \mathrm{M}$ & 28.39 & Matrix in silicified wallrock breccia \\
\hline $5 \mathrm{~N}-2,79-84 \mathrm{~V}$ & 28.39 & Large vug around silica clast in silicified wallrock breccia \\
\hline $9 X-1,15-22$ & 44.85 & Broken surface of massive pyrite breccia, with $\mathrm{cp}$ and py \\
\hline \multicolumn{3}{|l|}{ TAG-5 } \\
\hline $\begin{array}{r}158-957 \mathrm{O}- \\
4 \mathrm{R}-1,2-4\end{array}$ & 15.92 & Broken surface of vein-related pyrite-anhydrite breccia \\
\hline \multicolumn{3}{|l|}{ 158-957P- } \\
\hline $6 \mathrm{R}-1,5-7$ & 26.55 & Vein-related pyrite-anhydrite breccia \\
\hline $12 \mathrm{R}-4,86-93$ & 57.99 & Broken surface of massive granular pyrite \\
\hline
\end{tabular}

Note: $\mathrm{V}=$ vug or vein, $\mathrm{M}=$ matrix, $\mathrm{I}=$ interstitial, $\mathrm{py}=$ pyrite, $\mathrm{cp}=$ chalcopyrite, $\mathrm{hm}=$ hematite .
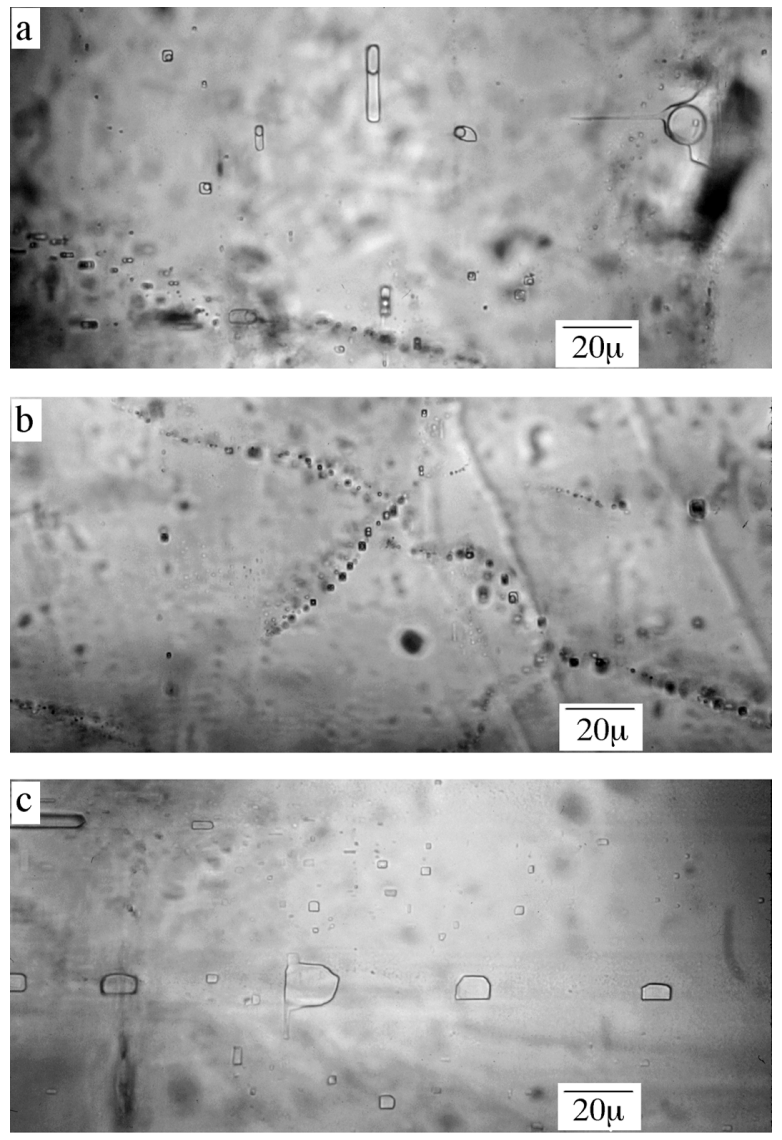

Figure 2. Photomicrographs of fluid inclusions in anhydrite from the TAG active mound. A. Primary two-phase fluid inclusions in Sample 158-957C$15 \mathrm{~N}-4,26-34$, from the TAG-1 area. B. Secondary, two-phase inclusions in Sample 158-957C-15N-4, 26-34, from the TAG-1 area. C. Decrepitated, empty inclusions in Sample 158-957P-12R-4, 86-93, from the TAG-5 area. ing and concomitant growth of the crystal [Roedder, 1984]). All inclusions exhibit uniform phase ratios.

\section{Fluid Inclusion Microthermometry}

For all fluid inclusions, final ice melting (Tm) occurs between $-3.1^{\circ}$ and $-0.7^{\circ} \mathrm{C}$ (Fig. 3), corresponding to salinities of 5.1 to $1.2 \mathrm{wt} \% \mathrm{NaCl}$ equivalent (Table 2). The range is about the same for samples from the TAG-1 and TAG-2 areas but much narrower for samples from the TAG5 area, where final melting occurs between $-2.4^{\circ}$ and $-1.9^{\circ} \mathrm{C}$, corresponding to salinities of 4.0 to $3.2 \mathrm{wt} \% \mathrm{NaCl}$ equivalent. In all samples from the TAG-5 area, one third of the samples from the TAG-2 area, and half the samples from the TAG-1 area, final ice melting temperatures correspond to salinities that are the same or greater than seawater salinity $(\sim 3.2 \mathrm{wt} \% \mathrm{NaCl})$. It is possible for there to be some increase in salinity in fluid inclusions hosted in anhydrite, both from anhydrite dissolution, and from hydration if anhydrite alters to gypsum. This is discussed further below. In half the samples from the TAG-1 area and two-thirds of the samples from the TAG-2 area, final ice melting temperatures correspond to a range of salinities ( 1.2 to $5.1 \mathrm{wt} \% \mathrm{NaCl}$ equivalent) both less than and greater than seawater salinity $(\sim 3.2 \mathrm{wt} \% \mathrm{NaCl})$. Final melting temperatures in secondary inclusions exhibit similar ranges as for primary inclusions for the same sample.

All fluid inclusions homogenize at temperatures (Th) between $168^{\circ}$ and $361^{\circ} \mathrm{C}$ (Fig. 4), which, when corrected for pressure effects, yield trapping temperatures (Tt) of 187 to $388^{\circ} \mathrm{C}$ (Table 2). Pressure corrections were carried out using properties for the $\mathrm{NaCl}-\mathrm{H}_{2} \mathrm{O}$ system, and data and equations from Bodnar (1993), assuming hydrostatic conditions. Samples from the TAG-5 area exhibit the lowest and largest temperature range, with homogenization temperatures of $168^{\circ}$ to $309^{\circ} \mathrm{C}$ and corresponding trapping temperatures of $187^{\circ}$ to $337^{\circ} \mathrm{C}$. In general, there are fewer intact fluid inclusions in individual anhydrite crystals from the TAG- 5 area, and a much greater abundance of what appear to be decrepitated, empty inclusions (Fig. 2C). Fluid inclusions from the TAG- 1 and TAG- 2 areas, with the exception of the shallowest sample examined from the TAG-2 area (with fluid inclusions that homogenize at $255^{\circ}$ to $287^{\circ} \mathrm{C}$ ), homogenize at greater than $310^{\circ} \mathrm{C}$, indicating trapping temperatures higher than $337^{\circ} \mathrm{C}$. For the same sample, homogenization and trapping tempera- 

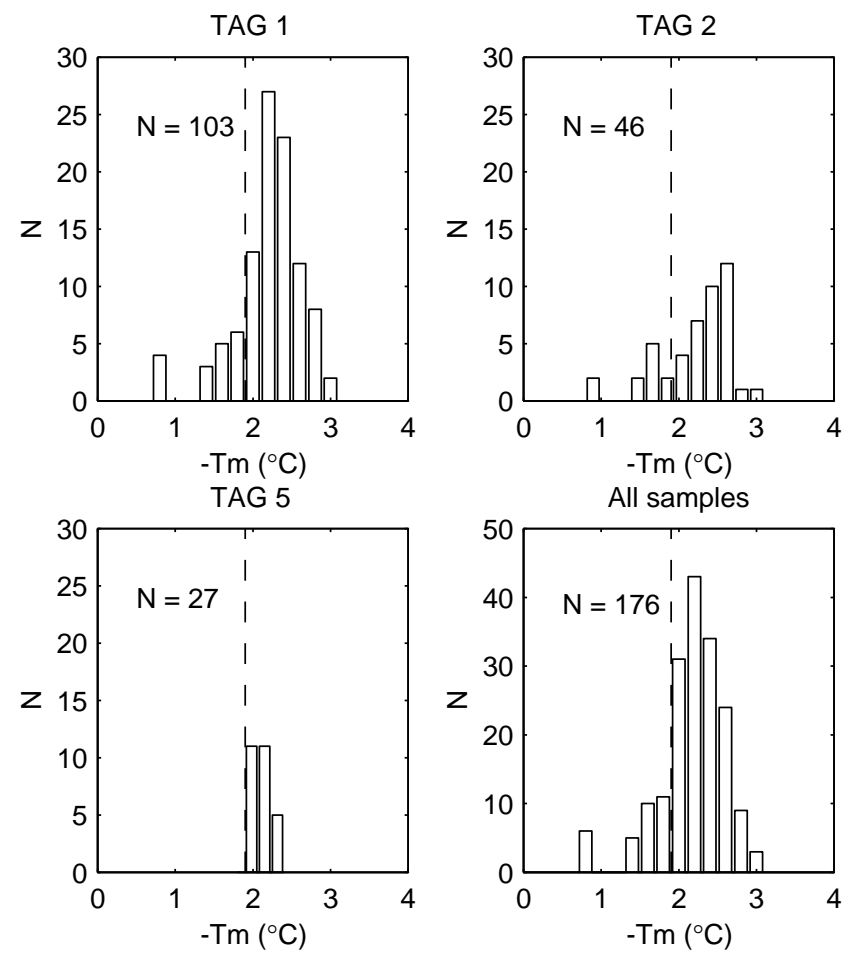

Figure 3. Frequency histograms of temperatures of final ice melting, Tm, for fluid inclusions in anhydrite from samples from the TAG-1, TAG-2, and TAG- 5 areas. $\mathrm{N}=$ number of samples. The dashed line indicates the temperature of final ice melting for a fluid of seawater salinity.

tures in secondary inclusions were similar as those for primary inclusions. With the exception of the shallowest sample from the TAG-2 area, for any given sample the range in $\mathrm{Tt}$ is less than $\sim 20^{\circ} \mathrm{C}$, and in Sample $158-957 \mathrm{H}-1 \mathrm{~N}-1$ it is less than $35^{\circ} \mathrm{C}$. In over half the samples, $\mathrm{Tt}$ is even more tightly clustered, exhibiting ranges of $10^{\circ} \mathrm{C}$ or less.

All fluid inclusions observed are two-phase, liquid-vapor inclusions. No daughter minerals were observed prior to microthermometric analyses. However, if crystals were left for over $12 \mathrm{hr}$ at room temperature $\left(\sim 20^{\circ} \mathrm{C}\right)$ after performing freezing runs, but before heating runs, fine-grained $(<1 \mu \mathrm{m})$ translucent daughter phases were observed. These grains disappeared upon heating to 108 to $120^{\circ} \mathrm{C}$, and did not reform unless the anhydrite crystal was frozen again and left to stand for many hours. Temperatures of final ice melting on individual inclusions before daughter phase formation, and after formation and subsequent dissolution by heating to $\sim 120^{\circ} \mathrm{C}$, were reproducible to $\pm 0.1^{\circ} \mathrm{C}$.

\section{DISCUSSION}

\section{Temperature}

The most striking feature of the microthermometry data from TAG active mound anhydrite crystals is the narrow range in trapping temperatures, particularly in samples from the TAG-1 area (where Tts differ by only $50^{\circ} \mathrm{C}$ ) and the TAG-2 area (where for depths of 18 mbsf and greater Tts differ by only $27^{\circ} \mathrm{C}$; Figs. 4, 5). In both areas there is a general increase in $\mathrm{Tt}$ with depth, from a maximum of $\sim 355^{\circ} \mathrm{C}$ near the top of the mound, to $369^{\circ} \mathrm{C}$ at $45 \mathrm{mbsf}$ in the TAG2 area, and to $388^{\circ} \mathrm{C}$ at $121 \mathrm{mbsf}$ in the TAG-1 area (Fig. 6). Maximum trapping temperatures in samples from near the top of the mound are about $10^{\circ} \mathrm{C}$ less than the highest measured temperature of black smoker fluid exiting the mound $\left(366^{\circ} \mathrm{C}\right.$; Edmond et al., 1995), and trapping temperatures in the shallowest sample from the TAG-2 area $(9.08 \mathrm{mbsf})$ are within $12^{\circ} \mathrm{C}$ of measured white smoker temper- atures (Tts of $280^{\circ}-313^{\circ} \mathrm{C}$ vs. measured temperatures of $273^{\circ}-$ $301^{\circ} \mathrm{C}$; Edmond et al., 1995). The correspondence of vent fluid temperatures to fluid inclusion trapping temperatures has been observed in samples from other active seafloor vent sites. For example, trapping temperatures of fluid inclusions in anhydrite crystals from vent deposits from the East Pacific Rise (EPR) at $13^{\circ} \mathrm{N}$ (Nehlig, 1991), the EPR at $21^{\circ} \mathrm{N}$ (LeBel and Oudin, 1982), and the Southern Juan de Fuca Ridge (JFR; Brett et al., 1987), in zinc sulfide crystals from vent deposits from the EPR at $21^{\circ} \mathrm{N}$ (LeBel and Oudin, 1982; Styrt et al., 1981), and in calcite crystals from vent deposits from Guaymas Basin, Gulf of California (Peter and Scott, 1988) are all in close agreement with measured temperatures of vent fluids exiting those deposits. A similar correspondence between measured vent fluid temperature and fluid inclusion trapping temperatures has been observed in anhydrite crystals recovered from depths of 236 to 256 mbsf at Middle Valley (JFR; Peter et al., 1994).

Within the TAG mound at depths greater than 43 mbsf in the TAG-1 area, Tts are consistently greater than the current temperature of black smoker fluids exiting the mound, reaching a maximum of $22^{\circ} \mathrm{C}$ greater $\left(388^{\circ} \mathrm{C}\right)$ at $121 \mathrm{mbsf}$. These data indicate that, at some point in time, fluids of $388^{\circ} \mathrm{C}$ or greater have circulated within the mound. The lack of trapping temperatures in excess of $366^{\circ} \mathrm{C}$ in the upper $30 \mathrm{~m}$ of the mound, the similarity of trapping temperatures in the shallowest sample from the TAG-2 area with measured temperatures of white smoker fluid, and the consistent increase in trapping temperatures with depth in samples from the TAG-1 and TAG-2 areas, suggests that current temperatures at depths of greater than 100 mbsf within the mound are, at least in some locations, in excess of $380^{\circ}$ to $390^{\circ} \mathrm{C}$.

Although inclusions in anhydrite from TAG-1 and TAG-2 area samples exhibit a narrow range in Tts, a much greater range is seen in the three samples from the TAG- 5 area where Tts differ by $150^{\circ} \mathrm{C}$. The highest trapping temperature, $337^{\circ} \mathrm{C}$, is from a depth of $26 \mathrm{mbsf}$. Fluid inclusions from crystals picked from the broken surface of the deepest sample recovered from the TAG-5 area (58 mbsf) exhibit much lower trapping temperatures, from $187^{\circ}$ to $207^{\circ} \mathrm{C}$. These data suggest two possible scenarios. The first is that temperatures of fluids forming anhydrite at depth in the TAG-5 area are currently cool relative to those in the TAG- 1 and TAG- 2 areas, possibly representing paths of seawater influx into the mound. The second possibility is that a past event of cooler fluid circulation has been succeeded by a more recent high temperature event. The observation, prior to heating and freezing measurements, of abundant decrepitated, empty inclusions in anhydrite crystals from the TAG-5 area (Fig. 2C) supports the latter scenario. Further speculation would require additional data from TAG-5 area samples.

\section{Salinity}

Salinities of fluid inclusions in anhydrite crystals also exhibit a relatively narrow range, from 1.2 to $5.1 \mathrm{wt} \% \mathrm{NaCl}$ equivalent (Table 2; Fig. 5). Unlike trapping temperatures, there is no corresponding general trend of salinities with depth in the TAG mound (Fig. 7). Salinities greater than those of currently measured TAG black smoker fluid can be attributed to higher salinity fluids circulating within the mound in the past. Dissolution of anhydrite or hydration of the host mineral to form gypsum, however, must also be considered (see below). Salinities lower than seawater can only be attributed to lower salinity fluids circulating within the mound in the past.

All of the salinities of the TAG fluid inclusions fall well within the range measured in mid-ocean ridge hydrothermal fluids $(\sim 0.2$ to $\sim 7$ wt\% $\mathrm{NaCl}$ equivalent; Von Damm, 1990; Butterfield and Massoth, 1994; Von Damm et al., 1995), and are similar to those reported from analyses of fluid inclusions in anhydrite crystals from vent deposits on the EPR at $21^{\circ} \mathrm{N}$ (LeBel and Oudin, 1982), the EPR at $13^{\circ} \mathrm{N}$ (Nehlig, 1991), and the Southern JFR (Brett et al., 1987), in zinc sulfide crystals from vent deposits on the EPR at $21^{\circ} \mathrm{N}$ (LeBel and Oudin, 1982; Styrt et al., 1981), and in vein quartz intergrown with sulfides 
Table 2. Summary of fluid inclusion analyses from anhydrite samples, TAG active hydrothermal mound.

\begin{tabular}{|c|c|c|c|c|c|c|}
\hline $\begin{array}{l}\text { Core, section, interval } \\
(\mathrm{cm})\end{array}$ & $\begin{array}{l}\text { Depth } \\
\text { (mbsf) }\end{array}$ & No.* & $\begin{array}{c}\text { Th } \\
\left({ }^{\circ} \mathrm{C} \text { range }\right)\end{array}$ & $\begin{array}{c}-\mathrm{Tm} \\
\left({ }^{\circ} \mathrm{C} \text { range }\right)\end{array}$ & $\frac{\mathrm{Tt}}{\left({ }^{\circ} \mathrm{C} \text { range }\right)^{+}}$ & $\begin{array}{l}\mathrm{NaCl} w t \% \\
\text { eq. } * *\end{array}$ \\
\hline $\begin{array}{l}\text { TAG-1 } \\
\text { ALV1677-2 }\end{array}$ & 0 & $\begin{array}{r}103 \\
10\end{array}$ & $311-326$ & $1.9-2.2$ & $338-353$ & $3.2-3.7$ \\
\hline $\begin{array}{l}158-957 \mathrm{C}- \\
7 \mathrm{~N}-1,126-128 \\
11 \mathrm{~N}-1,131-134 \\
11 \mathrm{~N}-3,121-123 \mathrm{~V} \\
11 \mathrm{~N}-3,121-123 \mathrm{I} \\
15 \mathrm{~N}-2,43-45 \\
15 \mathrm{~N}-4,26-34\end{array}$ & $\begin{array}{l}20.76 \\
32.01 \\
34.82 \\
34.82 \\
43.83 \\
46.66\end{array}$ & $\begin{array}{r}14 \\
1 \\
10 \\
12 \\
18 \\
10\end{array}$ & $\begin{array}{c}311-329 \\
336 \\
331-340 \\
334-342 \\
348-352 \\
340-348\end{array}$ & $\begin{array}{l}1.7-2.6 \\
2.1 \\
0.9-2.8 \\
0.7-2.5 \\
2.4-2.9 \\
1.5-2.5\end{array}$ & $\begin{array}{c}338-356 \\
363 \\
358-368 \\
362-369 \\
375-379 \\
368-375\end{array}$ & $\begin{array}{c}2.9-4.3 \\
3.5 \\
1.6-4.6 \\
1.2-4.2 \\
4.0-4.8 \\
2.6-4.2\end{array}$ \\
\hline $\begin{array}{l}\text { 158-957E- } \\
12 \mathrm{R}-1,0-3 \\
17 \mathrm{R}-1,8-15 \\
18 \mathrm{R}-1,19-25\end{array}$ & $\begin{array}{r}91.80 \\
116.18 \\
120.89\end{array}$ & $\begin{array}{r}14 \\
8 \\
6\end{array}$ & $\begin{array}{l}349-359 \\
336-354 \\
354-361\end{array}$ & $\begin{array}{l}1.9-2.8 \\
1.5-3.1 \\
1.8-2.6\end{array}$ & $\begin{array}{l}376-386 \\
365-381 \\
382-388\end{array}$ & $\begin{array}{l}3.2-4.6 \\
2.6-5.1 \\
3.1-4.3\end{array}$ \\
\hline $\begin{array}{l}\text { TAG-2 } \\
158-957 \mathrm{H}- \\
1 \mathrm{~N}-1,38-46 \\
3 \mathrm{~N}-1,53-63 \\
5 \mathrm{~N}-2,48-58 \\
5 \mathrm{~N}-2,79-84 \mathrm{M} \\
5 \mathrm{~N}-2,79-84 \mathrm{~V} \\
9 \mathrm{X}-1,15-22\end{array}$ & $\begin{array}{r}9.08 \\
18.23 \\
28.08 \\
28.39 \\
28.39 \\
44.85\end{array}$ & $\begin{array}{r}46 \\
\\
7 \\
6 \\
10 \\
5 \\
8 \\
10\end{array}$ & $\begin{array}{l}255-287 \\
315-327 \\
320-328 \\
321-331 \\
326-332 \\
326-342\end{array}$ & $\begin{array}{l}1.5-2.1 \\
1.7-2.8 \\
2.2-2.7 \\
0.8-2.6 \\
1.5-2.5 \\
2.1-3.1\end{array}$ & $\begin{array}{l}280-313 \\
342-354 \\
347-355 \\
349-358 \\
353-359 \\
354-369\end{array}$ & $\begin{array}{l}2.6-3.5 \\
2.9-4.6 \\
3.7-4.5 \\
1.4-4.3 \\
2.6-4.2 \\
3.5-5.1\end{array}$ \\
\hline $\begin{array}{l}\text { TAG-5 } \\
\text { 158-957O- } \\
\text { 4R-1, 2-4 }\end{array}$ & 15.92 & 27 & $250-252$ & $1.9-2.3$ & $274-277$ & $3.2-3.9$ \\
\hline $\begin{array}{l}158-957 \mathrm{P}- \\
6 \mathrm{R}-1,5-7 \\
12 \mathrm{R}-4,86-93\end{array}$ & $\begin{array}{l}26.55 \\
57.99\end{array}$ & $\begin{array}{r}16 \\
5\end{array}$ & $\begin{array}{l}293-309 \\
168-187\end{array}$ & $\begin{array}{l}1.9-2.2 \\
2.1-2.4\end{array}$ & $\begin{array}{l}319-337 \\
187-207\end{array}$ & $\begin{array}{l}3.2-3.7 \\
3.5-4.0\end{array}$ \\
\hline
\end{tabular}

Notes: Depth $=$ depth of sample below the top of the mound. $*$ Total number of measurements from each sample. ${ }^{+}$Temperatures corrected for entrapment pressure using equations of Zhang and Frantz (1987). **Salinities calculated using data and equations from Bodnar (1993). Th $=$ homogenization temperature. Tm $=$ final ice melting temperature, $v=$ vug or vein, $\mathrm{I}=$ interstitial, $\mathrm{M}=$ matrix.

TAG1

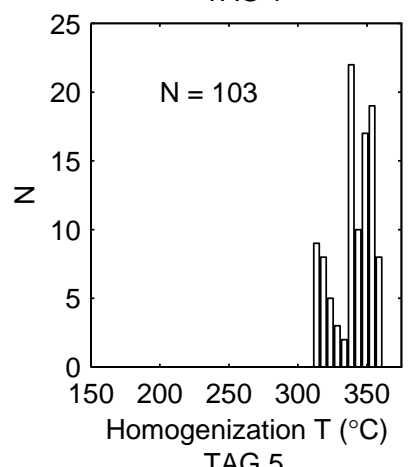

TAG5

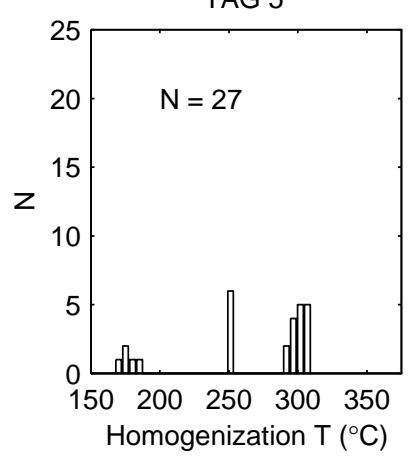

TAG2

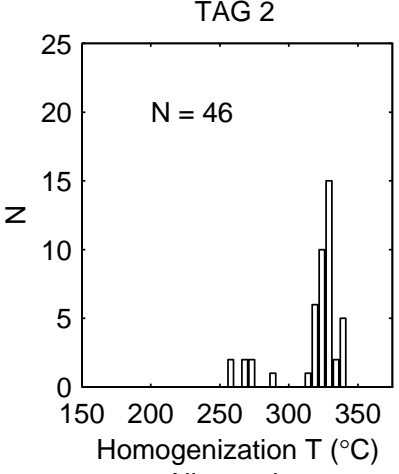

All samples

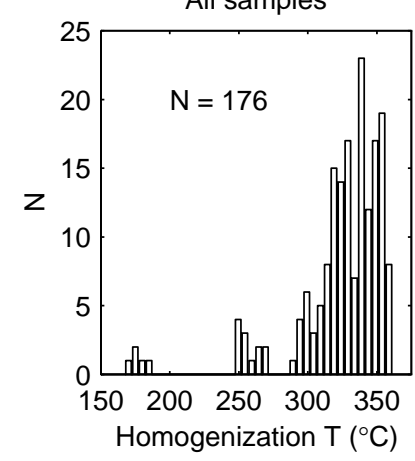

Figure 4. Frequency histograms of homogenization temperatures for fluid inclusions in anhydrite from samples from the TAG-1, TAG-2, and TAG-5 areas. $\mathrm{N}=$ number of samples.

from the Limni and Alestos ophiolitic sulfide ore deposits, Cyprus (Spooner and Bray, 1977). Similar ranges in salinities have also been observed in fluid inclusions in hydrothermally altered gabbro and breccia samples from the MARK and Hess Deep areas (Kelley and Delaney, 1987; Saccocia and Gillis, 1995; Kelley et al., 1993; Kelley and Malpas, 1996), in metagabbro, plagiogranite, and epidosite samples from the Oceanographer Transform, Mid-Atlantic Ridge (Vanko et al., 1992), in plagiogranite samples from the Semail Ophiolite (Nehlig, 1991), and in plagiogranite and gabbro samples from the upper level plutonic sequence, Troodos Ophiolite, Cyprus (Kelley and Robinson, 1990). In all of these igneous oceanic crust samples, several types of fluid inclusions are observed, some with salinities as high as 40 to $50 \mathrm{wt} \% \mathrm{NaCl}$ equivalent. In addition, separate populations of low-salinity ( $\sim 1$ to $8 \mathrm{wt} \% \mathrm{NaCl}$ equivalent), liquid-dominated fluid inclusions (commonly secondary, associated with microfractures) are observed. The favored explanation for generation of the high-salinity fluids is phase separation of either magmatic or seawater-derived fluids, and the favored model for generation of the low-salinity fluids is phase separation (either boiling or condensation) of seawater-derived fluids and/or variable mixing of hydrothermal seawater with phase-separated brines and vapors (Kelley and Delaney, 1987; Kelley and Robinson, 1990; Nehlig, 1991; Vanko et al., 1992; Kelley et al., 1993; Saccocia and Gillis, 1995; Kelley and Malpas, 1996). This model for low-salinity fluid generation is also the most likely explanation for the observed variability of salinities of mid-ocean ridge vent fluids (e.g., Von Damm and Bischoff, 1987; Von Damm, 1988; Edmonds and Edmond, 1995), and for the range of salinities observed in TAG anhydrite fluid inclusions.

For the TAG hydrothermal system, with minimum depths of $\sim 3630 \mathrm{mbsl}$, phase separation of a seawater-derived fluid would have to occur at temperatures and pressures in excess of the critical point $\left(407^{\circ} \mathrm{C}, 298\right.$ bars for a $3.2 \mathrm{wt} \% \mathrm{NaCl}$ solution; Bischoff and Rosenbauer, 1985), resulting in condensation, or separation of droplets of brine from a vapor-like fluid. As described by Kelley and Malpas (1996), if it is assumed that the lowest salinity fluids in TAG fluid inclusions were generated by supercritical phase separation, then a 
TAG1
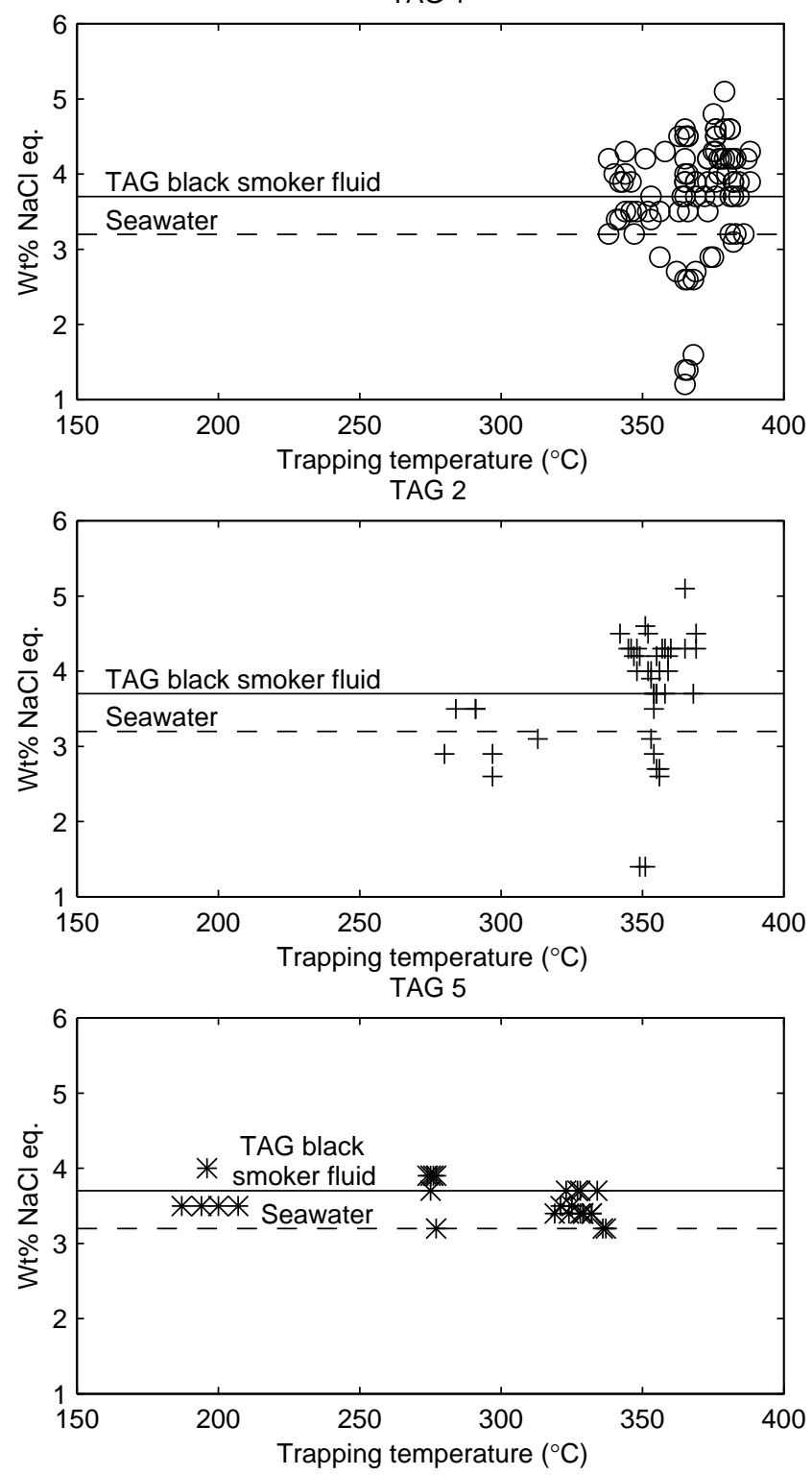

Figure 5. Trapping temperatures (pressure corrected) and corresponding salinities (wt $\% \mathrm{NaCl}$ equivalent) for fluid inclusions in anhydrite from samples from the TAG-1, TAG-2, and TAG-5 areas. Horizontal lines indicate salinities of TAG black smoker fluid (Edmond et al., 1995) and seawater.

maximum pressure estimate can be deduced based on the lowest salinity measured. The maximum pressure at which phase separation could occur and generate a low-salinity phase of $1.2 \mathrm{wt} \% \mathrm{NaCl}$ equivalent is $\sim 73 \mathrm{MPa}$ (Bodnar et al., 1985), corresponding to a depth of $\sim 7300 \mathrm{mbsl}$ assuming hydrostatic pressure. At greater pressures the low-salinity phase resulting from phase separation would be greater than $1.2 \mathrm{wt} \% \mathrm{NaCl}$ equivalent. However phase separation of a seawater-salinity fluid at $73 \mathrm{MPa}$ should also result in a brine phase of $\sim 40-50 \mathrm{wt} \% \mathrm{NaCl}$ equivalent (Bodnar et al., 1985), significantly greater than the maximum salinity $(5.1 \mathrm{wt} \% \mathrm{NaCl}$ equivalent) reported here. The lack of evidence for such high-salinity fluids suggests that phase separation likely occurred at shallower levels, where supercritical phase separation could still result in low-salinity phases of $\leq 1.2 \mathrm{wt} \% \mathrm{NaCl}$ equivalent, but also in lower salinity brine phases. Factors that complicate estimating the probable depth of phase sepa-
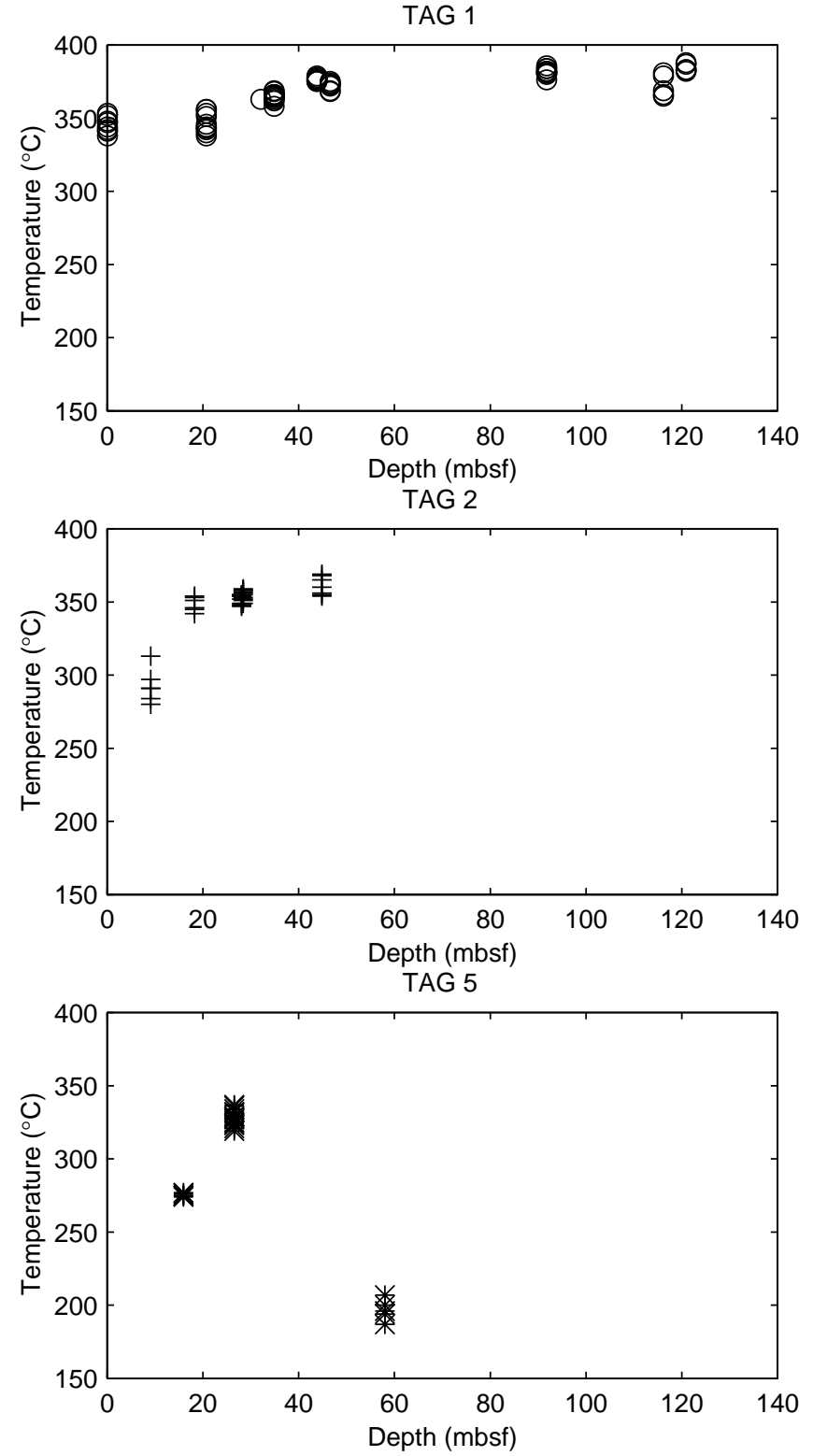

Figure 6. Trapping temperatures (pressure corrected) for fluid inclusions in anhydrite and corresponding depths of host samples from the TAG-1, TAG2 , and TAG- 5 areas.

ration based on TAG anhydrite fluid inclusion data include (1) Sr-isotope data indicate that the anhydrite crystals formed from mixtures of hydrothermal fluid and seawater, with proportions of hydrothermal fluid being at most $43 \%$ (see below), and (2) dissolution of anhydrite from inclusion walls may have increased the salinities of fluids within the inclusions by $\sim 0.65 \mathrm{wt} \%$ since entrapment (see below). Consideration of either of these factors would result in a lower minimum salinity of the hydrothermal fluid component, and would decrease the estimate of the maximum depth at which phase separation occurred to less than $7300 \mathrm{mbsl}$.

\section{Possible Problems with Inclusions in Anhydrite}

It is well known that there are concerns associated with analyzing fluid inclusions in anhydrite. These include possibilities of stretching of inclusions (Bodnar and Bethke, 1984), and partial dissolution of 

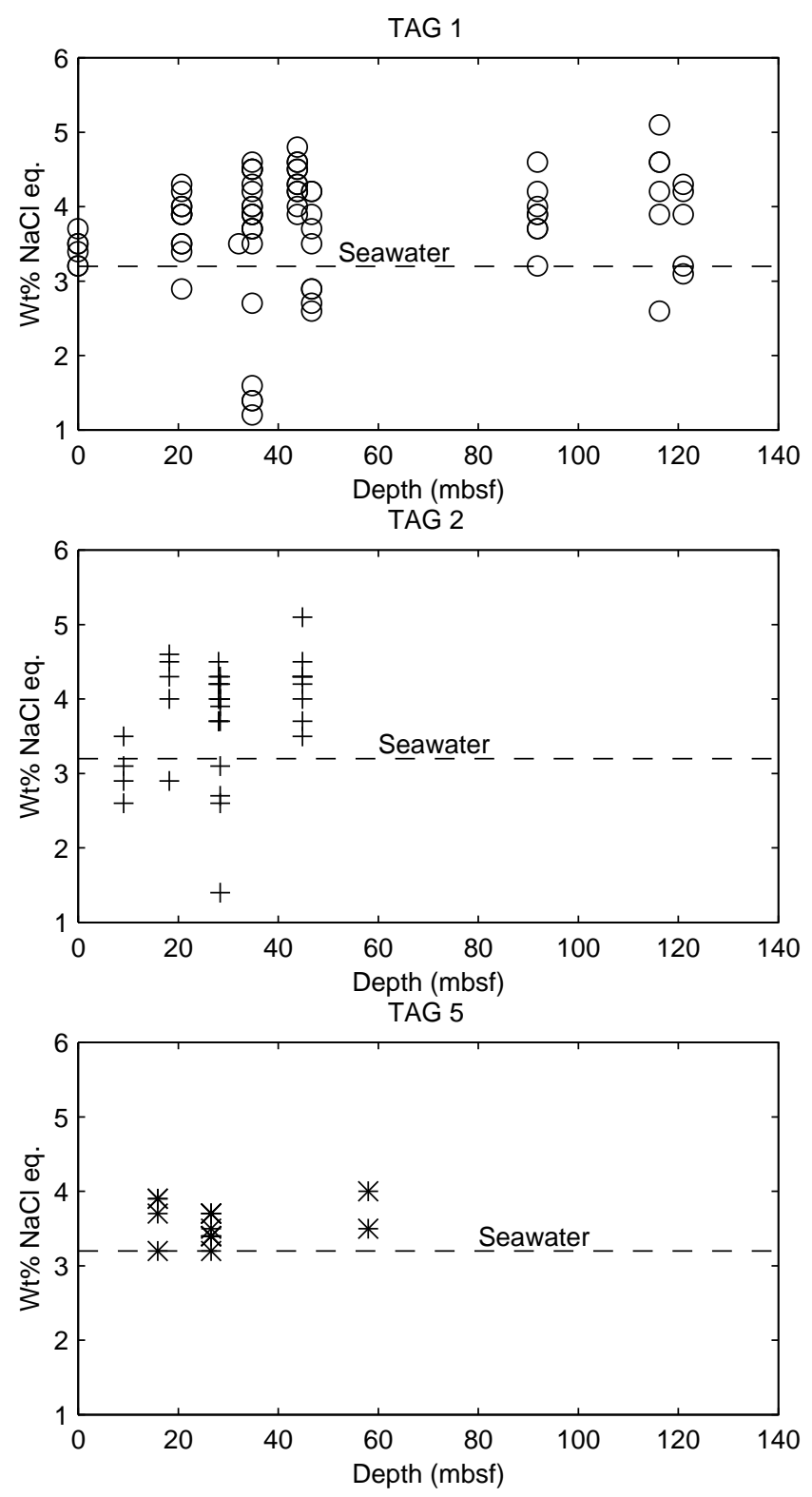

Figure 7. Salinities for fluid inclusions in anhydrite and corresponding depths of host samples from the TAG-1, TAG-2, and TAG-5 areas.

anhydrite, precipitation of anhydrite during heating, and formation of gypsum from reaction of anhydrite with the trapped aqueous fluid (LeBel and Oudin, 1982). All of these can affect the volume of the inclusion and thus homogenization temperatures. All but stretching can affect the salinity of the fluid in the inclusion. The consistency of the homogenization temperatures of inclusions along single arrays or in clusters, however, argues against any of these factors other than stretching being a major problem for homogenization temperatures in the samples analyzed. The consistency of temperatures of inclusions of a range of sizes and shapes, the similarity of temperatures of inclusions to temperatures of vent fluids exiting the mound and to temperatures of fluid inclusions in quartz from similar depths in the TAG active mound (Petersen et al., Chap. 13, this volume), argue against stretching being a major problem in the TAG samples analyzed.

In terms of salinity, both dissolution of anhydrite and reaction of anhydrite with aqueous fluid to form gypsum along the surface of the inclusion could increase the salinity of the fluid trapped in the inclusions. If the latter of these effects was substantial, however, the result should be a greater increase in salinity in smaller inclusions, with greater ratios of surface area to fluid volume. A general trend of greater salinities in smaller inclusions, however, is not observed. In fact a number of arrays exhibit inclusions of widely varying size with similar salinities (e.g., an array with 8-, 12-, and 25- $\mu \mathrm{m}$ inclusions all with $\mathrm{Tms}$ of $-2.2^{\circ} \mathrm{C}$, another array of $9-, 12-, 20-$, and $25-\mu \mathrm{m}$ inclusions all with $\mathrm{Tms}$ of $-2.3^{\circ} \mathrm{C}$, and another array with 4-, 20-, and 25$\mu \mathrm{m}$ inclusions, all with $\mathrm{Tms}$ of $-2.5^{\circ} \mathrm{C}$ ). For this reason it is assumed that there has not been a significant increase in salinity owing to dehydration from altering the surfaces of the inclusions to gypsum.

Salinity can also be affected by dissolution of anhydrite. If the $\mathrm{wt} \%$ of $\mathrm{CaSO}_{4}$ dissolved is controlled by solubility, then there could be a salinity increase that would be similar for all samples, and that would not be affected by inclusion size or shape. The observation that grains precipitated within inclusions following freezing runs (see above) indicates that possible increases in salinity owing to some dissolution of $\mathrm{CaSO}_{4}$ should be considered. That measured temperatures of final ice melting are reproducible to $\pm 0.1^{\circ} \mathrm{C}$ even after grains have precipitated and then dissolved at $\sim 120^{\circ} \mathrm{C}$, suggests that this dissolution is not taking place during freezing runs. Given the composition of the fluids and host mineral, the translucency of the grains, and that the grains dissolve upon heating to $\sim 120^{\circ} \mathrm{C}$, it is most likely that the grains are gypsum. Fluids in equilibrium with anhydrite at $\sim 350^{\circ} \mathrm{C}$ would contain only small amounts of Ca (e.g., only $2 \times 10^{-5} \mathrm{~mol} / \mathrm{kg}$ if the fluid was a mix of $80 \%$ seawater and $20 \%$ hydrothermal fluid; see below). At $20^{\circ} \mathrm{C}$ these same fluids would be undersaturated with anhydrite; some $\mathrm{CaSO}_{4}$ may have dissolved even given the very slow kinetics of anhydrite at temperatures less than $70^{\circ} \mathrm{C}$ (Blount and Dickson, 1973). For a solution close to the salinity of seawater, the solubility of gypsum is approximately $0.42 \mathrm{wt} \% \mathrm{CaSO}_{4}$, and that of anhydrite is approximately $0.65 \mathrm{wt} \% \mathrm{CaSO}_{4}$ (Deer et al., 1966; Posnjak, 1940). Assuming that some anhydrite has dissolved into the fluid in the inclusion, repeatedly lowering the temperature to $<-50^{\circ} \mathrm{C}$ could result in nucleation of grains of gypsum, which could then grow in slowly. Heating would result in dissolution of this gypsum; the 4-phase invariant equilibrium for $\mathrm{H}_{2} \mathrm{O}$, vapor, gypsum, and anhydrite is in the range from $50^{\circ}$ to $60^{\circ} \mathrm{C}$ (Blount and Dickson, 1973). Under this scenario the fluids in the inclusions may have dissolved enough anhydrite to increase the concentration of $\mathrm{CaSO}_{4}$ to $>0.42$ $\mathrm{wt} \%$, that is, enough so that gypsum is supersaturated at room temperature, and explaining the precipitation of gypsum grains when temperatures are dropped low enough to cause nucleation of gypsum. Assuming dissolution until saturation with anhydrite, the increase in salinity would be $\sim 0.65 \mathrm{wt} \%$.

The effect of such dissolution on the volume of the fluid inclusion must also be considered because this could affect homogenization temperatures. As discussed above, homogenization temperatures of inclusions in arrays, and even of all inclusions in a given crystal, are tightly clustered, suggesting that any volume change is insignificant. A simple calculation demonstrates that this is true. Assuming that the concentration of $\mathrm{CaSO}_{4}$ in the fluid in the inclusion is controlled by anhydrite solubility at $20^{\circ} \mathrm{C}$, then there would be $\sim 0.65 \mathrm{wt} \% \mathrm{CaSO}_{4}$, or $\sim 0.05 \mathrm{~mol} \mathrm{CaSO}_{4}$ per kg of $\mathrm{H}_{2} \mathrm{O}$. Assuming that when the inclusion formed the fluid contained essentially zero Ca (e.g., $2 \times 10^{-5} \mathrm{~mol} / \mathrm{kg}$; see below), the amount of anhydrite dissolved would be $0.05 \mathrm{~mol}$. The volume of anhydrite dissolved is calculated by considering the molar volume of anhydrite (anh) (Robie et al., 1979):

$$
\left(\frac{0.05 \mathrm{~mol} \mathrm{CaSO}_{4}}{\mathrm{~kg} \mathrm{H}_{2} \mathrm{O}}\right) \cdot\left(\frac{4.6 \times 10^{-5} \mathrm{~m}^{3}}{\mathrm{~mol} \mathrm{anh}}\right)=\frac{2.3 \times 10^{-6} \mathrm{~m}^{3} \mathrm{anh}}{\mathrm{kg} \mathrm{H}_{2} \mathrm{O}}
$$

The initial volume of a $20-\mu \mathrm{m}$ inclusion is

$$
\frac{4}{3} \pi r^{3}=\frac{4}{3} \pi \cdot\left(10^{-5} \mathrm{~m}\right)^{3} \cong 4 \times 10^{-15} \mathrm{~m}^{3}
$$


and would hold $\sim 4 \times 10^{-12} \mathrm{~kg} \mathrm{H}_{2} \mathrm{O}$. The amount of anhydrite that would dissolve into this amount of fluid is

$$
\left(\frac{2.3 \times 10^{-6} \mathrm{~m}^{3} \mathrm{anh}}{\mathrm{kg}}\right) \cdot 4 \times 10^{-12} \mathrm{~kg}=9.2 \times 10^{-18} \mathrm{~m}^{3}
$$

The dissolution of this amount of anhydrite results in an increase in volume of only $\sim 0.2 \%$.

The next point to consider is whether enough gypsum could form from this fluid to account for the small $(<1 \mu \mathrm{m})$ grains observed. Assuming that there is $0.65 \mathrm{wt} \% \mathrm{CaSO}_{4}$ dissolved in the fluid, and that the solubility of gypsum is $\sim 0.42 \mathrm{wt} \%$ at room temperature, then we need to consider what the volume is of $0.23 \mathrm{wt} \%$, or $0.017 \mathrm{~mol}$, $\mathrm{CaSO}_{4}$ as gypsum. Considering the molar volume of gypsum (Robie et al., 1979), this volume is

$$
\left(\frac{0.017 \mathrm{~mol} \mathrm{CaSO}_{4}}{\mathrm{~kg} \mathrm{H} \mathrm{O}}\right) \cdot\left(\frac{7.5 \times 10^{-5} \mathrm{~m}^{3}}{\mathrm{~mol}}\right) \cdot\left(4 \times 10^{-12} \mathrm{~kg} \mathrm{H}_{2} \mathrm{O}\right)=5.1 \times 10^{-18} \mathrm{~m}^{3}
$$

If this volume were present as 4 spherical grains, each would have a diameter of $\sim 0.7 \mu \mathrm{m}$, on the same order as the grains observed, to precipitate after freezing runs.

The calculations above demonstrate that dissolution of $\sim 0.65 \mathrm{wt} \%$ anhydrite, and precipitation of the amount of $\mathrm{CaSO}_{4}$ in excess of gypsum solubility at $20^{\circ} \mathrm{C}$, can account for the observed precipitation of grains after freezing runs. That such grains were observed in numerous inclusions whenever crystals were left at room temperature for a number of hours following freezing runs suggests that fluids in all inclusions may contain up to $0.65 \mathrm{wt} \% \mathrm{CaSO}_{4}$. Thus, salinities of fluids in inclusions are likely consistently $0.65 \mathrm{wt} \%$ greater than the salinities of the fluids initially trapped. As noted above, however, the minimal volume increase $(\sim 0.2 \%)$ would not significantly affect measured homogenization temperatures.

Thus, despite the concerns given above, the consistencies in homogenization temperatures suggest that dissolution of anhydrite, reaction to form gypsum, and deposition of anhydrite upon heating have not significantly altered the volume of the inclusions, and thus have not significantly affected homogenization temperatures. Dissolution of $\mathrm{CaSO}_{4}$ may have occurred, however, resulting in slight increases in salinity but probably not more than $0.65 \mathrm{wt} \%$.

\section{Implications for Entrainment and Mixing Processes}

Data on trapping temperatures and salinities from samples within the TAG active mound provide insight into entrainment and fluid mixing processes. As described above, trapping temperatures in samples from the TAG-1 and TAG-2 sites are all high, with many higher than the current measured temperature of fluids exiting black smokers. There is also a trend of increasing temperature with depth in both the TAG-1 and TAG-2 areas, with the cooler temperatures near the mound surface close to the highest measured temperatures of fluids exiting the mound. Because sulfate is virtually absent in black smoker fluid (Edmond et al., 1995), the sulfate in anhydrite must be of seawater origin. Sulfur-isotope data corroborate this assumption (Chiba et al., Chap. 6, this volume). Clearly seawater is being entrained into the mound and heated to temperatures close to that of the hottest hydrothermal fluid within the mound. The heating of seawater can be accomplished by a combination of mixing with hotter fluid, and conductive heating. Sr-isotopic analyses can be used both to estimate what proportion of $\mathrm{Ca}$ and $\mathrm{Sr}$ in anhydrite is from seawater vs. hydrothermal fluid and to determine mixing ratios. Sr-isotopic analyses carried out on anhydrite from the same samples used for the fluid inclusion study indicate hydrothermal fluid:seawater mixing ratios that range from 43:57 to 0.5:99.5 (Mills et al., Chap. 10, this volume). As with temperature, there is a trend in Sr-isotopic values with depth, with lesser amounts of hydrothermal fluid mixing with seawater at deeper levels within the mound (Table 3; Mills et al., Chap. 10, this volume). The increase in temperature from conductive heating required to bring the temperature of the mixture up to the temperatures recorded by fluid inclusions is also given in Table 3 . The simplest explanation for the decrease in the proportion of hydrothermal fluid with depth is a corresponding decrease in permeability with depth. In portions of the mound at depths of less than 45 mbsf, not only are there greater proportions of hydrothermal fluid mixing with seawater, but also much greater abundances of anhydrite (e.g., the lower bound of the anhydrite-rich zone is placed at 45 mbsf; Humphris et al., 1995; Humphris, Herzig, Miller, et al., 1996). The greater amounts of anhydrite imply that this part of the mound was, and may still be, more permeable. Thus, more seawater can be entrained, but also there can be more communication with hydrothermal fluid and seawater. At greater depths it is likely that the permeability is significantly lower, and there is a greater likelihood that entrained seawater will not be able to mix with as much hydrothermal fluid.

The calculated mixing proportions from $\mathrm{Sr}$-isotope data and the corresponding fluid trapping temperatures from anhydrite samples can also be used, along with published compositions of end-member black smoker fluid (Edmond et al., 1995), to calculate amounts of anhydrite that should precipitate from various mixtures. Previous calculations by Tivey et al. (1995) indicate that a mix of $80 \%$ seawater and $20 \%$ black smoker fluid at $350^{\circ} \mathrm{C}$ would be in equilibrium with anhydrite ( $\sim 93 \%$ of total precipitate), chrysotile ( $7 \%$ of total precipitate), trace amounts of hematite, and talc. If calculations are done with precipitation of MHSH (.75) (magnesium hydroxysulfate hydrate ([.75]); Janecky and Seyfried, 1983) considered, the same mixture is in equilibrium with anhydrite ( $80 \%$ of total precipitate), MHSH (16\% of total precipitate), and trace amounts of talc and hematite. If these calculations are redone with precipitation of chrysotile, talc, and MHSH suppressed (because they have not been identified in drill core samples; Humphris, Herzig, Miller, et al., 1996), then $1.43 \times 10^{-2}$ mol anhydrite, $2.66 \times 10^{-5} \mathrm{~mol}$ chalcopyrite, and $3.7 \times 10^{-4} \mathrm{~mol}$ hematite are calculated to precipitate per kg of fluid. Only $2 \times 10^{-5} \mathrm{~mol} / \mathrm{kg}$ Ca remains in solution. Precipitation of chalcopyrite and hematite increases the acidity of the remaining solution, which can then react with previously deposited minerals within the mound. The prediction that at $350^{\circ} \mathrm{C} \mathrm{MHSH}$ and talc should be in equilibrium with mixtures of hydrothermal fluid and seawater, and the lack of MHSH or talc observed in core samples, may indicate either a problem with thermodynamic data used in equilibrium calculations, or problems with kinetics. If it is the latter, then the implication is that anhydrite is precipitating fairly rapidly. This is also suggested by oxygen-isotope analyses of anhydrite (Chiba et al., Chap. 6, this volume).

Data discussed above provide evidence for entrainment of seawater into the mound, and heating of this seawater by mixing with hot hydrothermal fluid, and by conductive heat gain. Simple calculations that consider conductive heating of hydrothermal fluid:seawater mixtures were carried out by Tivey et al. (1995) to examine whether the amounts of conductive heating required to heat fluids to near $350^{\circ} \mathrm{C}$ were reasonable, and to estimate possible rates of flow of entrained seawater. Calculations were carried out by considering heat gain by fluid flowing through a hollow cylinder, assuming that the outer layer is maintained at a constant temperature, $T_{o}$. The temperature, $T_{F}$, of the fluid exiting the end of the cylinder of length $L$ is given by:

$$
T_{F}=\left(T_{i}-T_{o}\right) e^{-\left[\frac{2 \pi \mathrm{K} L}{F C_{p} 1 \mathrm{n}\left(r_{2} / r_{1}\right)}\right]}+T_{\mathrm{o}}
$$

where $T_{i}$ is the initial temperature of the seawater, or hydrothermal fluid/seawater mix entering the cylinder, $\kappa$ is thermal conductivity of the wall of the cylinder, $F$ is fluid flow rate, $C_{p}$ is specific heat capacity of the fluid, and $r_{2}$ and $r_{1}$ are the radii of the outer and inner walls 
Table 3. Ratios of hydrothermal fluid and seawater in fluids that formed anhydrite crystals and corresponding maximum trapping temperatures in anhydrite crystals.

\begin{tabular}{|c|c|c|c|c|c|c|}
\hline $\begin{array}{l}\text { Core, section, } \\
\text { interval }(\mathrm{cm})\end{array}$ & $\begin{array}{l}\text { Depth } \\
\text { (mbsf) }\end{array}$ & ${ }^{87} \mathrm{Sr} /{ }^{\beta 6} \mathrm{Sr}$ & $\begin{array}{l}\text { HF:SW } \\
\text { ratio }\end{array}$ & $\begin{array}{l}\mathrm{T}\left({ }^{\circ} \mathrm{C}\right) \\
\text { of mix }\end{array}$ & $\begin{array}{c}\operatorname{Max} \mathrm{Tt} \\
\left({ }^{\circ} \mathrm{C}\right)\end{array}$ & $\begin{array}{c}\text { T gain* } \\
\left({ }^{\circ} \mathrm{C}\right)\end{array}$ \\
\hline $\begin{array}{l}\text { TAG-1 } \\
\text { ALV1677-2 }\end{array}$ & 0 & 0.707214 & $29: 71$ & 205 & 353 & 148 \\
\hline $\begin{array}{l}158-957 \mathrm{C}- \\
11 \mathrm{~N}-1,131-134 \\
11 \mathrm{~N}-3,121-123 \mathrm{I} \\
11 \mathrm{~N}-3,121-123 \mathrm{~V}\end{array}$ & $\begin{array}{l}32.01 \\
34.82 \\
34.82\end{array}$ & $\begin{array}{l}0.706370 \\
0.707283 \\
0.706846\end{array}$ & $\begin{array}{l}43: 57 \\
28: 72 \\
35: 65\end{array}$ & $\begin{array}{l}250 \\
202 \\
220\end{array}$ & $\begin{array}{l}363 \\
369 \\
368\end{array}$ & $\begin{array}{l}113 \\
167 \\
148\end{array}$ \\
\hline $\begin{array}{l}158-957 \mathrm{E}- \\
17 \mathrm{R}-1,8-15 \\
18 \mathrm{R}-1,19-25\end{array}$ & $\begin{array}{l}116.18 \\
120.89\end{array}$ & $\begin{array}{l}0.708155 \\
0.709128\end{array}$ & $\begin{array}{c}15: 85 \\
0.5: 99.5\end{array}$ & $\begin{array}{r}110 \\
5\end{array}$ & $\begin{array}{l}381 \\
388\end{array}$ & $\begin{array}{l}271 \\
383\end{array}$ \\
\hline $\begin{array}{l}\text { TAG-2 } \\
158-957 \mathrm{H}- \\
1 \mathrm{~N}-1,38-46 \\
5 \mathrm{~N}-2,79-84 \mathrm{~V} \\
9 \mathrm{X}-1,15-22\end{array}$ & $\begin{array}{r}9.08 \\
28.08 \\
44.85\end{array}$ & $\begin{array}{l}0.707251 \\
0.707249 \\
0.706866\end{array}$ & $\begin{array}{l}29: 71 \\
29: 71 \\
35: 65\end{array}$ & $\begin{array}{l}205 \\
205 \\
220\end{array}$ & $\begin{array}{l}313 \\
359 \\
369\end{array}$ & $\begin{array}{l}108 \\
154 \\
149\end{array}$ \\
\hline $\begin{array}{l}\text { TAG-5 } \\
158-957 \mathrm{P}- \\
12 \mathrm{R}-4,86-93\end{array}$ & 57.99 & 0.708847 & $4.5: 95.5$ & 32 & 207 & 175 \\
\hline
\end{tabular}

Notes: Proportions of hydrothermal fluid and seawater (HF:SW) were calculated using $\mathrm{Sr}$-isotope data and concentrations of $\mathrm{Sr}$ in hydrothermal fluid and seawater (see Mills et al., Chap. 10, this volume). Temperatures from mixing were calculated by considering the heat capacities of $3.2 \mathrm{wt} \% \mathrm{NaCl}$ solutions at $40 \mathrm{MPa}$ (Bischoff and Rosenbauer, 1985) and relative volumes of the two fluids. *Temperature increase that must be achieved by conductive heating.

of the cylinder, respectively (Seewald and Seyfried, 1990; Tivey et al., 1995). The value used for thermal conductivity of the inner walls of the cylinder is an average value based on measured thermal conductivities of breccia samples from the mound (Rona et al., Chap. 24 , this volume), extrapolated to $350^{\circ} \mathrm{C}$ (Tivey, Chap. 16, this volume). Table 4 gives results of calculations done as part of this study. Results indicate that flow rates must be less than $\sim 0.1 \mathrm{~kg} / \mathrm{s}$ in order for the fluids forming anhydrite to be conductively heated. The time for the fluid to traverse from the outside of the mound to the inside would be $\sim 4$ to $9 \mathrm{hr}$. The amount of anhydrite that would precipitate in the mound per year from this flow rate is $2 \mathrm{~m}^{3}$.

A final related calculation to consider is an estimate of how much seawater could be entrained and heated within the mound, given that the seawater or hydrothermal fluid/seawater mix must be heated to $>338^{\circ} \mathrm{C}$. Rona et al. (1993) calculated a convective heat flux from the Black Smoker Complex of $225 \mathrm{MW}$. If we use $5 \%$ of this heat as an estimate of the energy being used to heat seawater from $2^{\circ}$ to $\sim 360^{\circ} \mathrm{C}$, then $\sim 6 \mathrm{~kg} / \mathrm{s}$ can be heated:

$$
\frac{\left(225 \cdot 10^{6} \mathrm{~J} / \mathrm{s}\right) \cdot(0.05)}{(5250 \mathrm{~J} / \mathrm{kgK}) \cdot\left(358^{\circ}\right)}=6 \mathrm{~kg} / \mathrm{s}
$$

where $5250 \mathrm{~J} \mathrm{~kg}^{-1} \mathrm{~K}^{-1}$ is the average heat capacity of seawater at $2^{\circ}$ and $360^{\circ} \mathrm{C}$ and 400 bars (Bischoff and Rosenbauer, 1985). This corresponds to 60 separate channels or veins each carrying $\sim 0.1 \mathrm{~kg} / \mathrm{s}$. The amount of anhydrite that would precipitate per year in the mound from this rate of seawater entrainment, assuming precipitation of $\sim 0.0143 \mathrm{~mol}$ anhydrite per kilogram fluid, is $\sim 120 \mathrm{~m}^{3}$. If only $1 \%$ of $225 \mathrm{MW}$ is used to heat seawater, the flow rate is $1.2 \mathrm{~kg} / \mathrm{s}$ and the amount of anhydrite precipitated per year is $\sim 24 \mathrm{~m}^{3}$, and if $10 \%$ of $225 \mathrm{MW}$ is used then the flow rate is $12 \mathrm{~kg} / \mathrm{s}$ and $240 \mathrm{~m}^{3}$ of anhydrite would precipitate per year. An estimate of the amount of anhydrite within the mound can also be made. If we assume that the anhydrite enriched zone, with an upper bound 10-20 mbsf, and a lower bound at $\sim 45$ mbsf (Humphris et al., 1995), is represented by a 50-
Table 4. Flow rates, distances, and times required to achieve sufficient conductive heating.

\begin{tabular}{lrcrrccc}
\hline $\begin{array}{c}\mathrm{T}_{F} \\
\left({ }^{\circ} \mathrm{C}\right)\end{array}$ & $\begin{array}{c}\mathrm{T}_{i} \\
\left({ }^{\circ} \mathrm{C}\right)\end{array}$ & $\begin{array}{c}\mathrm{T}_{o} \\
\left({ }^{\circ} \mathrm{C}\right)\end{array}$ & $\begin{array}{c}L \\
(\mathrm{~m})\end{array}$ & $r_{2} / r_{l}$ & $\begin{array}{c}F^{*} \\
(\mathrm{~kg} / \mathrm{s})\end{array}$ & $\begin{array}{c}V^{*} \\
(\mathrm{~m} / \mathrm{s})\end{array}$ & $\begin{array}{c}t \\
(\mathrm{hr})\end{array}$ \\
\hline $388^{* *}$ & 2 & 390 & 100 & 100 & 0.040 & 0.15 & 8.8 \\
$388^{* *}$ & 2 & 390 & 100 & 10 & 0.080 & 0.31 & 4.4 \\
369 & 200 & 370 & 50 & 100 & 0.017 & 0.04 & 8.3 \\
369 & 200 & 370 & 50 & 10 & 0.034 & 0.08 & 4.2 \\
369 & 200 & 370 & 100 & 100 & 0.034 & 0.08 & 8.3 \\
369 & 200 & 370 & 100 & 10 & 0.067 & 0.16 & 4.2 \\
\hline
\end{tabular}

Notes: Temperature, $T_{F}$, of fluid heated by conduction as it flows at a rate $F$ through a hollow cylinder of length $L$, and inner and outer radii of $r_{1}$ and $r_{2}$, respectively, was calculated using Equation 5 (see text). $T_{i}$ is the initial temperature of the fluid, and the outer side of the cylinder is maintained at constant temperature $T_{o}$. Velocity $V$ is related to flow rate by $F=V \pi r_{1}^{2} \rho$ where $\rho$ is the density of the fluid. Time is $t=L /$ $V$. Values used in Equation 5 for $\kappa, C_{p}, \rho$, and $r_{1}$ are $8 \mathrm{~W} \mathrm{~m}^{-1} \mathrm{~K}^{-1}$ (approximate thermal conductivity of breccias if extrapolated to $350^{\circ} \mathrm{C}$ from room temperature, see Tivey [Chap. 16, this volume]), $6300 \mathrm{~J} \mathrm{~kg}^{-1} \mathrm{~K}^{-1}$ and $670 \mathrm{~kg} \mathrm{~m}^{-3}$ (values for seawater at $\sim 360^{\circ} \mathrm{C}$ and $40 \mathrm{MPa}$; Bischoff and Rosenbauer, 1985), and $0.01 \mathrm{~m}$. Two values of $r_{2}, 1 \mathrm{~m}$ and $0.1 \mathrm{~m}$, are considered. $*=$ Flow rates or velocities of greater than these values will not result in sufficient conductive heating to achieve $T_{F} * * *$ Average values of $C_{p}$ and $r$ were used $\left(5200 \mathrm{~J} \mathrm{~kg}^{-1} \mathrm{~K}^{-1}\right.$ and $830 \mathrm{~kg} \mathrm{~m}^{-3}$; Bischoff and Rosenbauer, 1985).

m-diameter cylinder, $30 \mathrm{~m}$ thick, containing roughly $1 / 3$ anhydrite, then there is $\sim 2 \times 10^{4} \mathrm{~m}^{3}$ of anhydrite present in the mound. The length of time required to deposit this volume of anhydrite, assuming flow rates of 1.2 to $12 \mathrm{~kg} / \mathrm{s}$, is 80 to $800 \mathrm{yr}$.

\section{CONCLUSIONS}

Data from fluid inclusions in anhydrite provide evidence for high temperatures $\left(>337^{\circ} \mathrm{C}\right)$ throughout the TAG-1 and TAG-2 areas, and suggest that temperatures at depths of greater than 100 mbsf within the mound are currently in excess of $380^{\circ}$ to $390^{\circ} \mathrm{C}$. Heating of entrained seawater results from mixing with hydrothermal fluid, and by conductive heat gain as fluids are transported through veins bounded by conductive sulfide-rich breccias. Flow rates in individual veins are estimated to be less than $0.1 \mathrm{~kg} / \mathrm{s}$. This convective process of entraining and heating seawater to $>337^{\circ} \mathrm{C}$ may well result in cooling of black smoker fluids from $\sim 390^{\circ} \mathrm{C}$ at $125 \mathrm{mbsf}$ to current exit temperatures of $366^{\circ} \mathrm{C}$.

Salinities of fluids in inclusions all fall well within the range measured in mid-ocean ridge hydrothermal fluids. Dissolution of anhydrite into fluids trapped in inclusions may have occurred, but increases in salinity are likely less than $0.66 \mathrm{wt} \%$. Sr-isotope analyses allow determination of the proportions of hydrothermal fluid and seawater in the fluid mixtures from which anhydrite formed (Mills et al., Chap. 10 , this volume). A general trend of decreasing amounts of hydrothermal fluid in mixtures with depth is consistent with a corresponding decrease in permeability. Geochemical calculations that consider mixtures of hydrothermal fluid and seawater in proportions indicated by $\mathrm{Sr}$-isotopic analyses, and at temperatures recorded by fluid inclusion trapping temperatures, predict that on the order of $10^{-2} \mathrm{~mol}$ of anhydrite should precipitate per kilogram of fluid. Small amounts of sulfide and hematite should also precipitate, resulting in an increase in the acidity of the remaining solution, which can then react with previously deposited minerals within the mound.

The significance of seawater entrainment within the TAG active mound is underscored by the presence of a large volume of anhydrite, estimated to be on the order of $2 \times 10^{4} \mathrm{~m}^{3}$. Whether or not such entrainment, which not only results in deposition of anhydrite, but also in the generation of acidic fluids and subsequent metal remobiliza- 
tion, is anomalous to the TAG active hydrothermal mound, or is going on to various degrees at all vent sites, needs to be investigated.

\section{ACKNOWLEDGMENTS}

Fluid inclusion data were collected in the laboratory of K.M. Gillis. Her help and advice are gratefully acknowledged. The manuscript has benefited from reviews by M. Boni and D. Kelley. This work was supported by USSAC under JOI-USSSP Account No. 158-20889 to MKT.

\section{REFERENCES}

Becker, K., and Von Herzen, R.P., 1996. Pre-drilling observations of conductive heat flow at the TAG active mound using Alvin. In Humphris, S.E., Herzig, P.M., Miller, D.J., et al., Proc. ODP, Init. Repts., 158: College Station, TX (Ocean Drilling Program), 23-29.

Bischoff, J.L., and Rosenbauer, R.J., 1985. An empirical equation of state for hydrothermal seawater (3.2 percent NaCl). Am. J. Sci., 285:725-763.

Blount, C.W., and Dickson, F.W., 1973. Gypsum-anhydrite equilibria in systems $\mathrm{CaSO}_{4}-\mathrm{H}_{2} \mathrm{O}$ and $\mathrm{CaSO}_{4}-\mathrm{NaCl}-\mathrm{H}_{2} \mathrm{O}$. Am. Mineral., 58:323-331.

Bodnar, R.J., 1993. Revised equation and table for determining the freezing point depression of $\mathrm{H}_{2} \mathrm{O}-\mathrm{NaCl}$ solutions. Geochim. Cosmochim. Acta, 57:683-684.

Bodnar, R.J., and Bethke, P.M., 1984. Systematics of stretching of fluid inclusions, I: fluorite and sphalerite at 1 atmosphere confining pressure. Econ. Geol., 79:141-161.

Bodnar, R.J., Burnham, C.W., and Sterner, S.M., 1985. Synthetic fluid inclusions in natural quartz. III. Determinations of phase equilibrium properties in the system $\mathrm{H}_{2} \mathrm{O}-\mathrm{NaCl}$ to $1000^{\circ} \mathrm{C}$ and 1500 bars. Geochim. Cosmochim. Acta, 49:1861-1873.

Brett, R., Evans, H.T., Jr., Gibson, E.K., Jr., Hedenquist, J.W., Wandless, M.V., and Sommer, M.A., 1987. Mineralogical studies of sulfide samples and volatile concentrations of basalt glasses from the southern Juan de Fuca Ridge. J. Geophys. Res., 92:11,373-11,379.

Butterfield, D.A., and Massoth, G.J., 1994. Geochemistry of north Cleft segment vent fluids: temporal changes in chlorinity and their possible relation to recent volcanism. J. Geophys. Res., 99:4951-4968.

Deer, W.A., Howie, R.A., and Zussman, J., 1966. An Introduction to the Rock-Forming Minerals: New York (Wiley).

Ding, K., and Seyfried, W.E., Jr., 1992a. Determination of Fe-Cl complexing in the low pressure supercritical region $(\mathrm{NaCl}$ fluid): iron solubility constraints on $\mathrm{pH}$ of subseafloor hydrothermal fluids. Geochim. Cosmochim. Acta, 56:3681-3692.

- 1992b. Experimental determination of $\mathrm{Cu}-\mathrm{Cl}$ speciation at the T-P conditions relevant to ridge crest hydrothermal activity: implications to

$\log \left(\mathrm{fO}_{2}\right)$ in the hot spring fluids. Eos, 73:254.
Edmond, J.M., Campbell, A.C., Palmer, M.R., German, C.R., Klinkhammer, G.P., Edmonds,

H.N., Elderfield, H., Thompson, G., and Rona, P., 1995. Time series studies of vent fluids from the TAG and MARK sites (1986, 1990): MidAtlantic Ridge: a new solution chemistry model and a mechanism for $\mathrm{Cu}$ / Zn zonation in massive sulfide ore bodies. In Parson, L.M., Walker, C.L., and Dixon, D.R. (Eds.), Hydrothermal Vents and Processes. Geol. Soc. Spec. Publ. London, 87:77-86.

Edmonds, H.N., and Edmond, J.M., 1995. A three-component mixing model for ridge crest hydrothermal fluids. Earth Planet. Sci. Lett., 134:53-67.

Humphris, S.E., Herzig, P.M., Miller, D.J., et al., 1996. Proc. ODP, Init. Repts., 158: College Station, TX (Ocean Drilling Program).

Humphris, S.E., Herzig, P.M., Miller, D.J., Alt, J.C., Becker, K., Brown, D., Brügmann, G., Chiba, H., Fouquet, Y., Gemmell, J.B., Guerin, G., Hannington, M.D., Holm, N.G., Honnorez, J.J., Itturino, G.J., Knott, R., Ludwig, R., Nakamura, K., Petersen, S., Reysenbach, A.-L., Rona, P.A., Smith, S., Sturz, A.A., Tivey, M.K., and Zhao, X., 1995. The internal structure of an active sea-floor massive sulphide deposit. Nature, 377:713-716.
Janecky, D.R., and Seyfried, W.E., 1983. The solubility of magnesiumhydroxide-sulfate-hydrate in seawater at elevated temperatures and pressures. Am. J. Sci., 283:831-860.

Johnson, J.W., Oelkers, E.H., and Helgeson, H.C., 1992. SUPCRT92: a software package for calculating the standard molal thermodynamic properties of minerals, gases, aqueous species, and reactions from 1 to $5000 \mathrm{Bar}$ and 0 to $1000^{\circ}$ C. Comput. Geosci., 18:899-947.

Kelley, D.S., and Delaney, J.R., 1987. Two-phase separation and fracturing in mid-ocean ridge gabbros at temperatures greater than $700^{\circ} \mathrm{C}$. Earth Planet. Sci. Lett., 83:53-66.

Kelley, D.S., Gillis, K.M., and Thompson, G., 1993. Fluid evolution in submarine magma-hydrothermal systems at the Mid-Atlantic Ridge. J. Geophys. Res., 98:19,579-19,596.

Kelley, D.S., and Malpas, J., 1996. Melt-fluid evolution in gabbroic rocks from Hess Deep. In Mével, C., Gillis, K.M., Allan, J.F., and Meyer, P.S. (Eds.), Proc. ODP, Sci. Results, 147: College Station, TX (Ocean Drilling Program), 213-226.

Kelley, D.S., and Robinson, P.T., 1990. Development of a brine-dominated hydrothermal system at temperatures of $400-500^{\circ} \mathrm{C}$ in the upper level plutonic sequence, Troodos ophiolite, Cyprus. Geochim. Cosmochim. Acta, 54:653-661.

Lalou, C., Reyss, J.L., Brichet, E., Arnold, M., Thompson, G., Fouquet, Y., and Rona, P.A., 1993. New age data for Mid-Atlantic Ridge hydrothermal sites: TAG and Snakepit geochronology revisited. J. Geophys. Res., 98:9705-9713.

Lalou, C., Thompson, G., Arnold, M., Brichet, E., Druffel, E., and Rona, P.A., 1990. Geochronology of TAG and Snakepit hydrothermal fields, Mid-Atlantic Ridge: witness to a long and complex hydrothermal history. Earth Planet. Sci. Lett., 97:113-128.

Le Bel, L., and Oudin, E., 1982. Fluid inclusion studies of deep-sea hydrothermal sulphide deposits on the East Pacific Rise near $21^{\circ} \mathrm{N}$. Chem. Geol., 37:129-136.

Mills, R.A., and Elderfield, H., 1995. Rare earth element geochemistry of hydrothermal deposits from the active TAG mound, $26^{\circ} \mathrm{N}$ Mid-Atlantic Ridge. Geochim. Cosmochim. Acta, 59:3511-3524.

Mitra, A., Elderfield, H., and Greaves, M.J., 1994. Rare earth element distribution in submarine hydrothermal fluids and plumes from the Mid-Atlantic Ridge. Mar. Chem., 47:217-236.

Nehlig, P., 1991. Salinity of oceanic hydrothermal fluids: a fluid inclusion study. Earth Planet. Sci. Lett., 102:310-325.

Peter, J.M., Goodfellow, W.D., and Leybourne, M.I., 1994. Fluid inclusion petrography and microthermometry of the Middle Valley hydrothermal system, northern Juan de Fuca Ridge. In Mottl, M.J., Davis, E.E., Fisher, A.T., and Slack, J.F. (Eds.), Proc. ODP, Sci. Results, 139: College Station, TX (Ocean Drilling Program), 411-428.

Peter, J.M., and Scott, S.D., 1988. Mineralogy, composition, and fluid-inclusion microthermometry of seafloor hydrothermal deposits in the southern trough of Guaymas Basin, Gulf of California. Can. Mineral., 26:567587.

Posnjak, E., 1940. Deposition of calcium sulphate from seawater. Am. J. Sci., 238:559.

Robie, R.A., Hemingway, B.S., and Fisher, J.R., 1979. Thermodynamic properties of minerals and related substances at $298.15 \mathrm{~K}$ and 1 bar (10 Pascals) pressure and at higher temperatures. Geol. Soc. Am. Bull., 1452.

Roedder, E., 1984. Fluid inclusions. Rev. Mineral., Mineral. Soc. Am., 12.

Rona, P.A., Hannington, M.D., Raman, C.V., Thompson, G., Tivey, M.K., Humphris, S.E., Lalou, C., and Petersen, S., 1993. Active and relict seafloor hydrothermal mineralization at the TAG hydrothermal field, MidAtlantic Ridge. Econ. Geol., 88:1987-2013.

Saccocia, P.J., and Gillis, K.M., 1995. Hydrothermal upflow zones in the oceanic crust. Earth Planet. Sci. Lett., 136:1-16.

Seewald, J.S., and Seyfried, W.E., Jr., 1990. The effect of temperature on metal mobility in subseafloor hydrothermal systems: constraints from basalt alteration experiments. Earth Planet. Sci. Lett., 101:388-403.

Spooner, E.T.C., and Bray, C.J., 1977. Hydrothermal fluids of sea water salinity in ophiolitic sulphide ore deposits in Cyprus. Nature, 266:808812.

Styrt, M.M., Brackmann, A.J., Holland, H.D., Clark, B., Pisutha-Arnond, Eldridge, C.S., and Ohmoto, H., 1981. The mineralogy and isotopic com- 
position of sulfur in hydrothermal sulfide/sulfate deposits on the East Pacific Rise, $21^{\circ} \mathrm{N}$ latitude. Earth Planet. Sci. Lett., 53:382-390.

Sverjensky, D.A., Hemley, J.J., and d'Angelo, W.M., 1991. Thermodynamic assessment of hydrothermal alkali feldspar-mica-aluminosilicate equilibria. Geochim. Cosmochim. Acta, 4:989-1004.

Thompson, G., Humphris, S.E., Schroeder, B., Sulanowska, M., and Rona, P.A., 1988. Active vents and massive sulfides at $26^{\circ} \mathrm{N}$ (TAG) and $23^{\circ} \mathrm{N}$ (Snakepit) on the Mid-Atlantic Ridge. Can. Mineral., 26:697-711.

Tivey, M.K., Humphris, S.E., Thompson, G., Hannington, M.D., and Rona, P.A., 1995. Deducing patterns of fluid flow and mixing within the TAG active hydrothermal mound using mineralogical and geochemical data. $J$. Geophys. Res., 100:12,527-12,555.

Tivey, M.K., and McDuff, R.E., 1990. Mineral precipitation in the walls of black smoker chimneys: a quantitative model of transport and chemical reaction. J. Geophys. Res., 95:12617-12637.

Vanko, D.A., Griffith, J.D., and Erickson, C.L., 1992. Calcium-rich brines and other hydrothermal fluids in fluid inclusions from plutonic rocks, Oceanographer Transform, Mid-Atlantic Ridge. Geochim. Cosmochim. Acta, 56:35-47.

Von Damm, K.L., 1988. Systematics of and postulated controls on submarine hydrothermal solution chemistry. J. Geophys. Res., 93:4551-4561.
, 1990. Seafloor hydrothermal activity: black smoker chemistry and chimneys. Annu. Rev. Earth Planet. Sci., 18:173-204.

Von Damm, K.L., and Bischoff, J.L., 1987. Chemistry of hydrothermal solutions from the southern Juan de Fuca Ridge. J. Geophys. Res., 92:11,334-11,346.

Von Damm, K.L., Oosting, S.E., Kozlowski, R., Buttermore, L.G., Colodner, D.C., Edmonds, H.N., Edmond, J.M., and Grebmeier, J.M., 1995. Evolution of East Pacific Rise hydrothermal vent fluids following a volcanic eruption. Nature, 375:47-50.

Westall, J.C., Zachary, J.L., and Morel, F.M.M., 1976. MINEQL, a computer program for the calculation of chemical equilibrium composition of aqueous systems. Mass. Inst. Technol., Dep. Civ. Eng., Tech. Note, 18.

Zhang, Y., and Frantz, J.D., 1987. Determination of the homogenization temperatures and densities of supercritical fluids in the system $\mathrm{NaCl}-\mathrm{KCl}-$ $\mathrm{CaCl}_{2}-\mathrm{H}_{2} \mathrm{O}$ using synthetic fluid inclusions. Chem. Geol., 64:335-350.

Date of initial receipt: 3 June 1996

Date of acceptance: 10 January 1997

Ms 158SR-211 